Causes and Triggers of Mass-Movements: Overloading

Short title: Causes and Triggers of Mass-Movements: Overloading

\title{
Causes and Triggers of Mass-Movements: Overloading
}

\section{Alain Demoulin ${ }^{\mathrm{a}, \mathrm{b}}$}

Hans-Balder Havenith

aFRS-FNRS, Brussels, Belgium

bUnit of Physical Geography and Quaternary, Đépartement de GéographieDepartment of Geography, University of Liege, Liege, Belgium

'Department of Geology, University of Liege, Liege, Belgium

\section{Introduction}

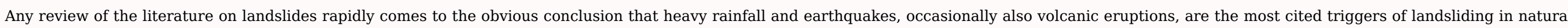

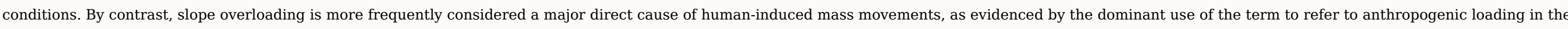

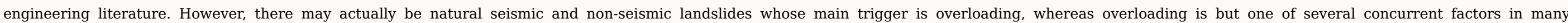
anthropogenic landslides.

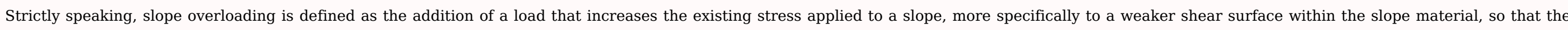

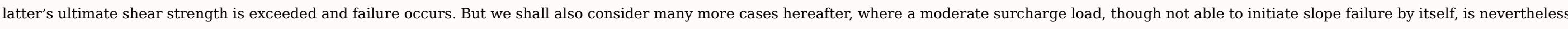

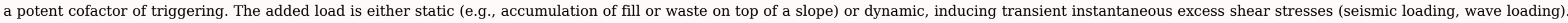

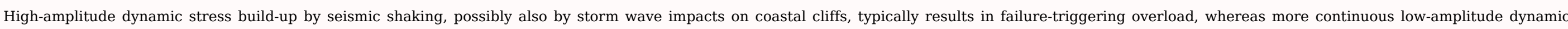

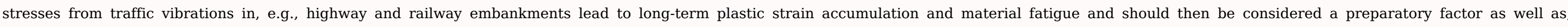
occasionally, the eventual trigger of slope instability.

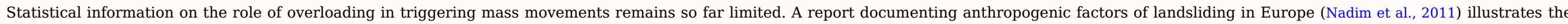

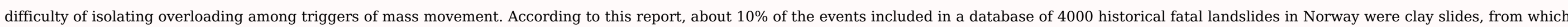

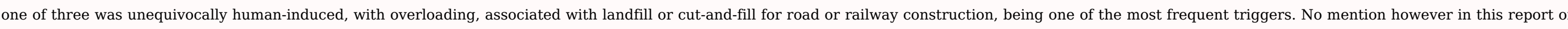

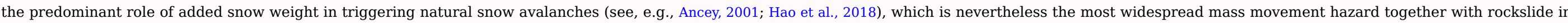

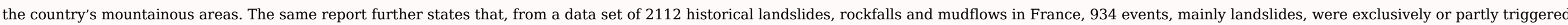

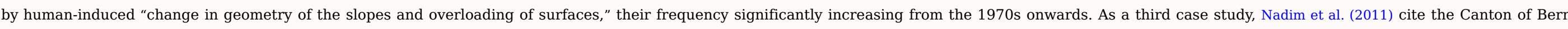

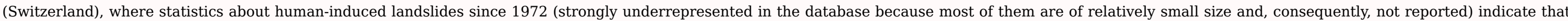

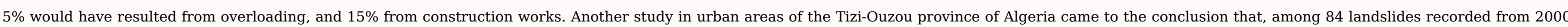

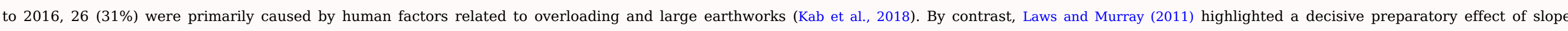

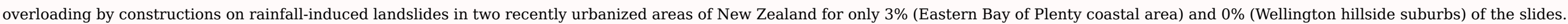

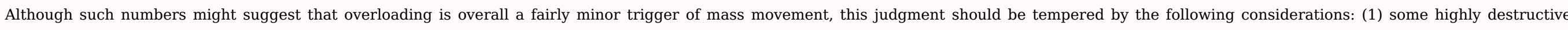

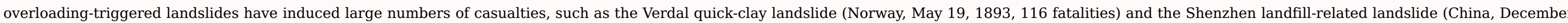

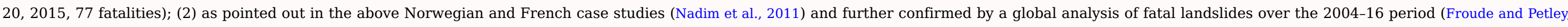

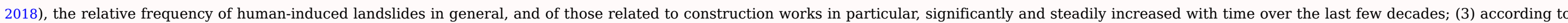




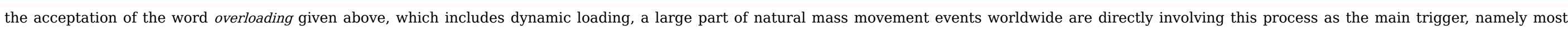

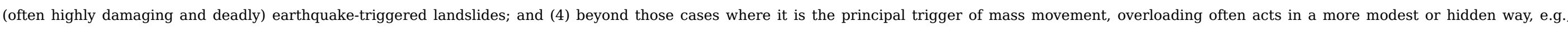

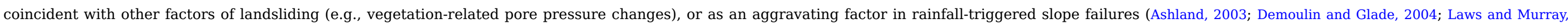
2011).

\section{Overloading and the balance between resistant and driving forces}

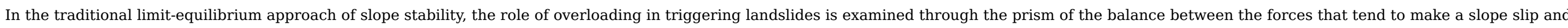

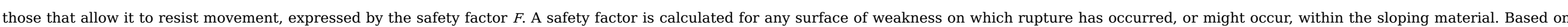
the Terzaghi (1936) theory, the factor of safety is defined and calculated as

$F=$ soil shear strength $/$ shear stress $=\left[C+\left(W_{n}-U\right) * \operatorname{tg} \varphi\right] / W_{t}$

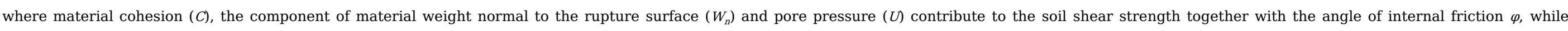
the component of material weight parallel to the rupture surface $\left(W_{t}\right)$ is the driving stress (Fig. 1).

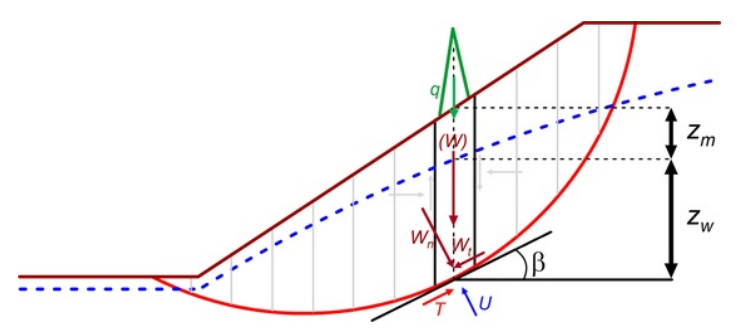

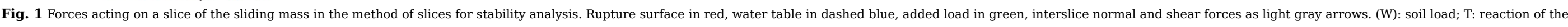
slice base to the exerted forces; other labels: see Eq. (2) and related paragraph of the main text.

\section{alt-text: Fig. 1}

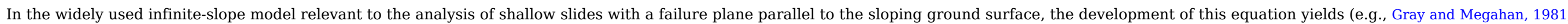
Hammond et al., 1992; Selby, 1993):

$$
F=\frac{c^{\prime}+c_{r}+\left[q+\gamma_{m} z_{m}+\left(\gamma_{s a t}-\gamma_{w}\right) z_{w}\right] \cos ^{2} \beta \tan \varphi^{\prime}}{\left[q+\gamma_{m} z_{m}+\gamma_{s a t} z_{w}\right] \cos \beta \sin \beta}
$$

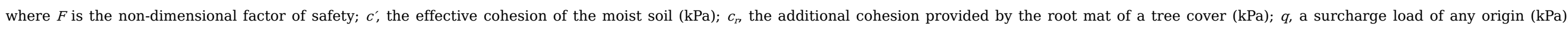

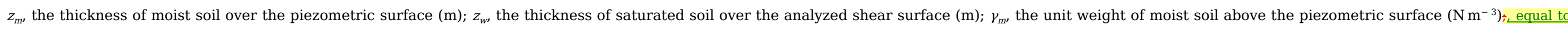

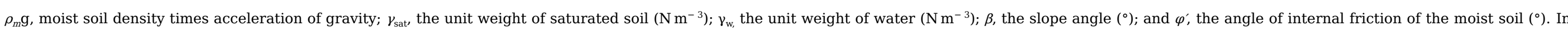

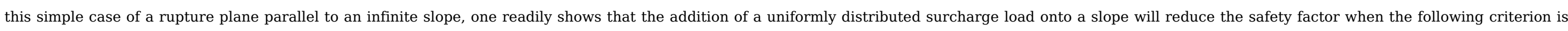
satisfied:

$c^{\prime}+c_{r}>\gamma_{w} z_{w} \cos ^{2} \beta \tan \varphi^{\prime}$

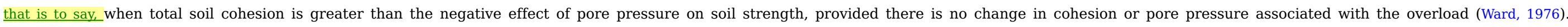

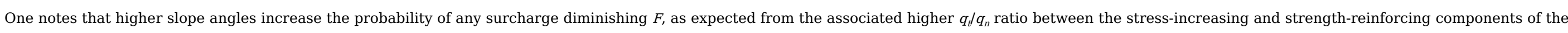

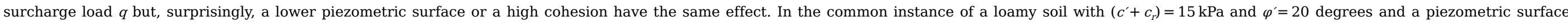

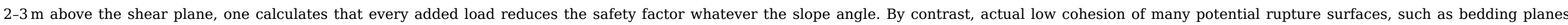




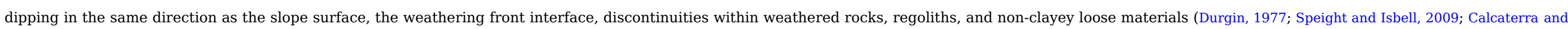

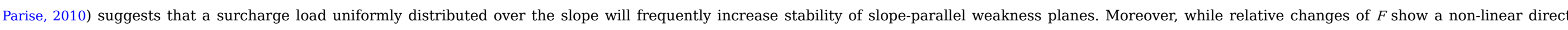

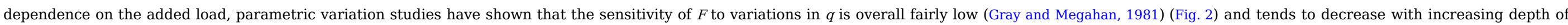
the rupture plane (Mulder, 1991).

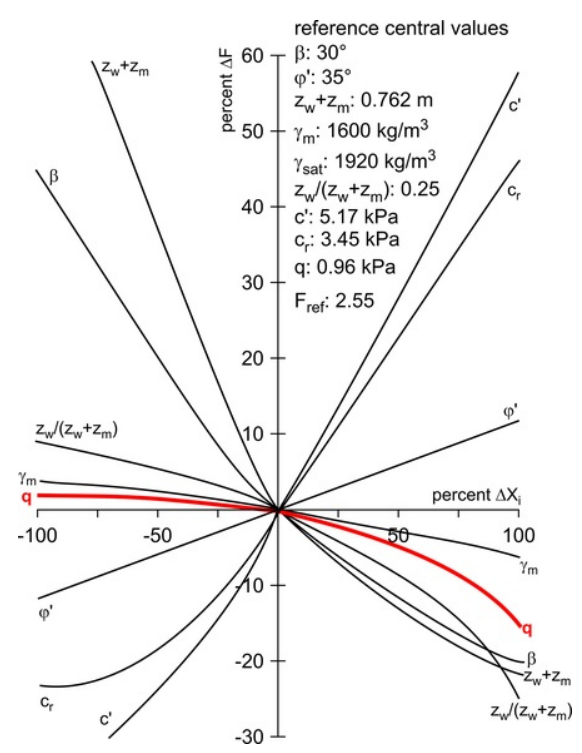

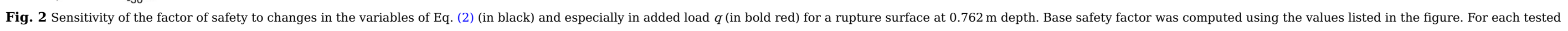
variable, the $\mathrm{X}$ axis expresses the departure from the central value as a percentage.

Redrawn after Gray D and Megahan W (1981) Forest Vegetation Removal and Slope Stability in the Idaho Batholith. USDA, Research Paper INT-271: Ogden, Utah, p. 23.

\section{alt-text: Fig. 2}

In the special case where the surcharge results from the growth of tall trees and, thus, also implies an increase in root cohesion $\Delta c_{r}$ (see below), the condition for decreased $F$ becomes

$$
q>\Delta c_{r} \frac{\left(\gamma_{m} z_{m}+\gamma_{s a t} z_{w}\right)}{\left(c^{\prime}+c_{r 0}-\gamma_{w} z_{w} \cos ^{2} \beta \tan \varphi^{\prime}\right)}
$$

Here, the condition explicitly defines a minimum value that the surcharge has to exceed in order to degrade $F$ but, again, does not directly inform about the sensitivity of $F$ to $q$.

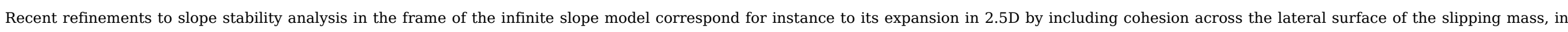

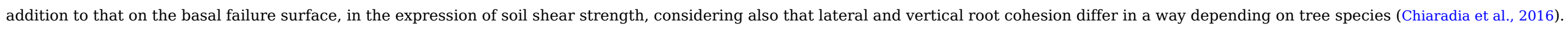

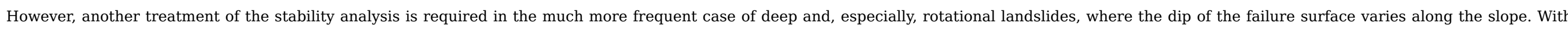

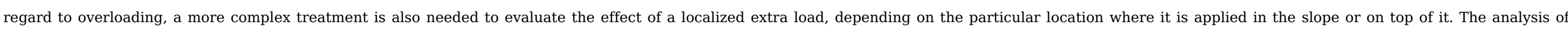

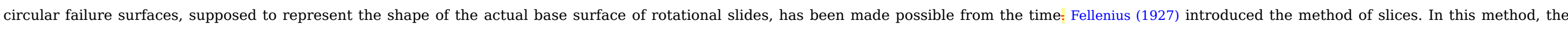

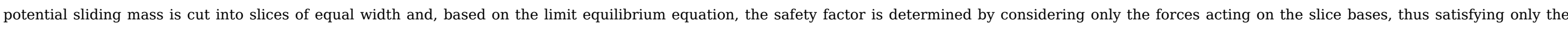

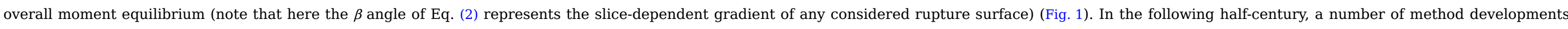

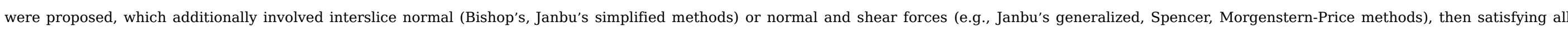

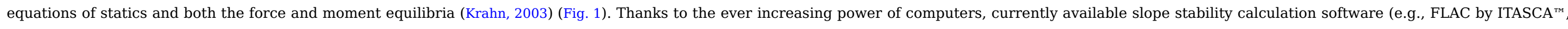




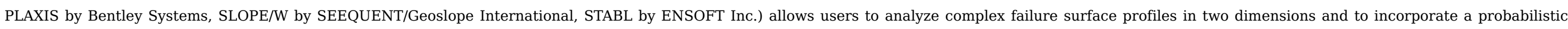

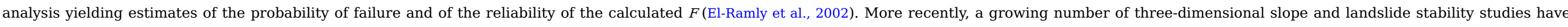

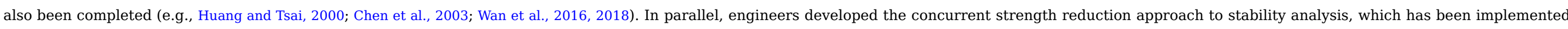

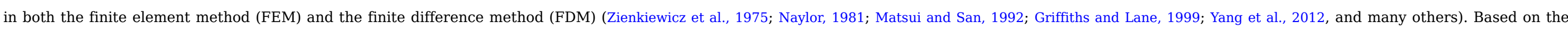

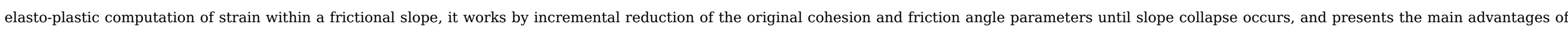

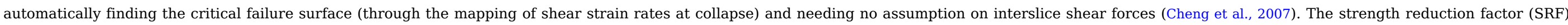
yielded by this method is an exact equivalent of the safety factor of the limit equilibrium method (Griffiths and Lane, 1999).

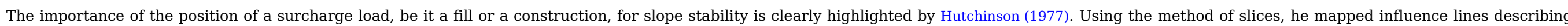
the positive or negative impact of an additional load at any place along or above a slope. For a given weight and shape of the load and a fixed rupture surface, one simply maps the ratio:

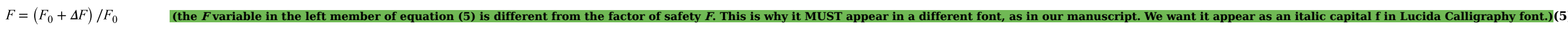

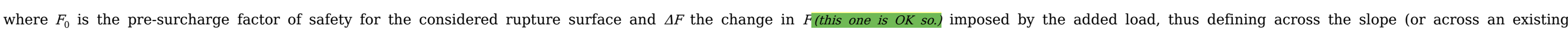

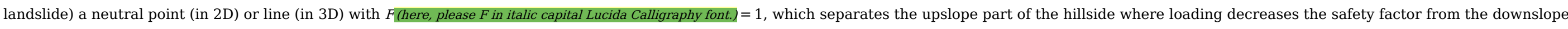

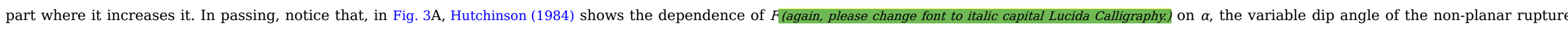

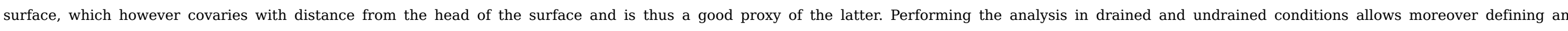

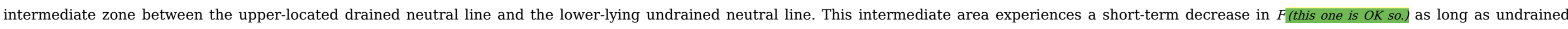

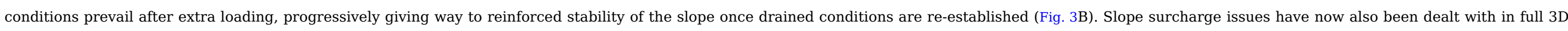
(e.g., Cheng et al., 2015) and using FEM (e.g., Sazzad and Haque, 2014).

(A)

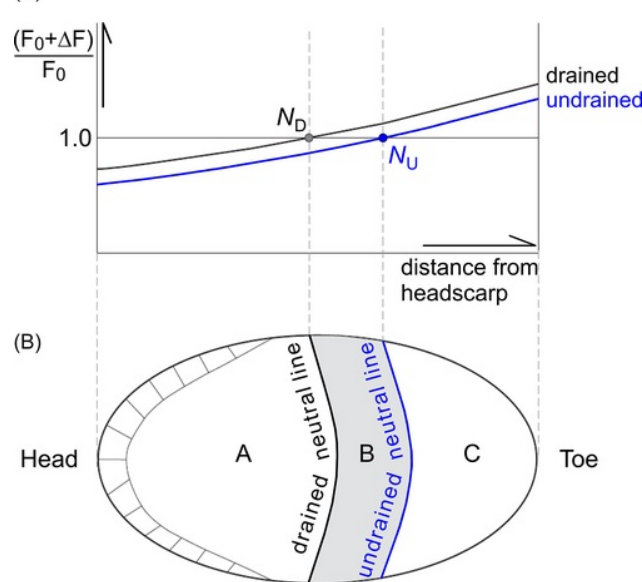

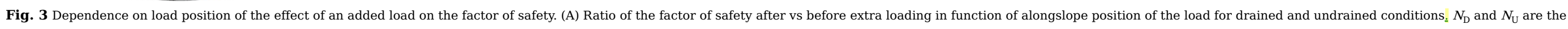
neutral points (no change in $F$ ) in drained and undrained conditions, respectively. (B) Plan view of a landslide highlighting the intermediate zone (B) of time-dependent evolution of the post-loading factor of safety.

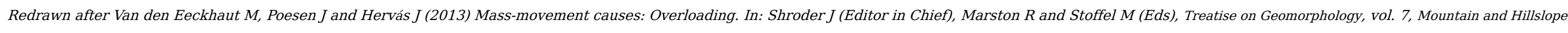

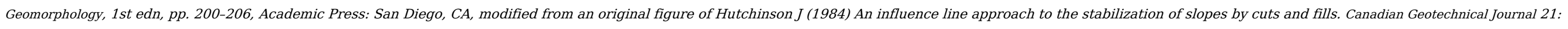
363-370.

alt-text: Fig. 3 


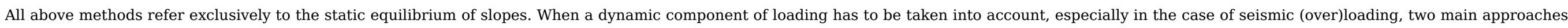

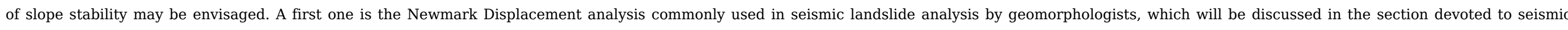

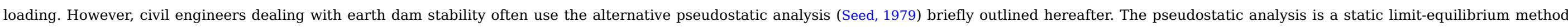

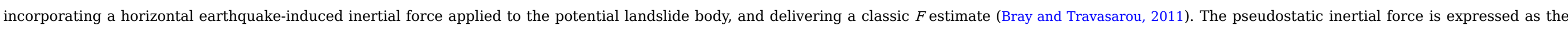

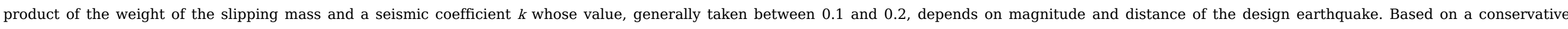

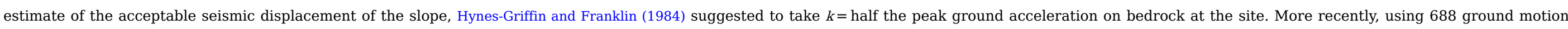

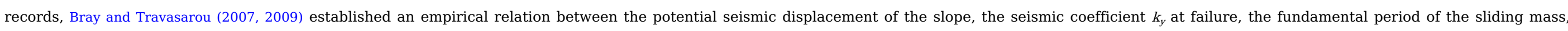

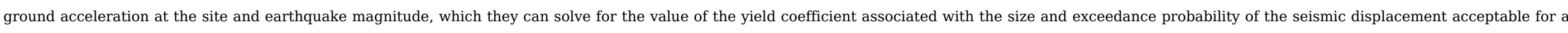

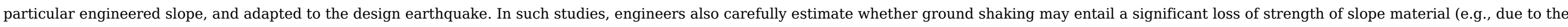
presence of liquefiable layers), thus imposing the use of dynamic strength parameters lower than their static counterpart.

\section{Types of overloading}

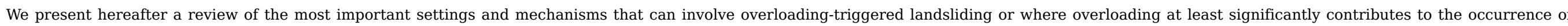
landslides.

\subsection{Overloading by higher-located slides}

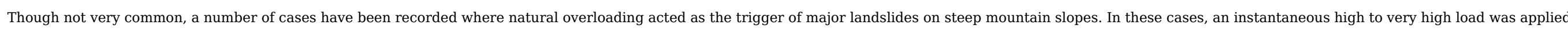

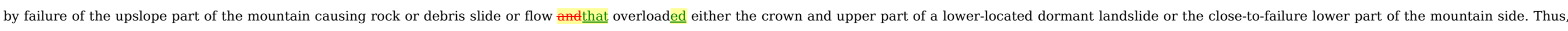

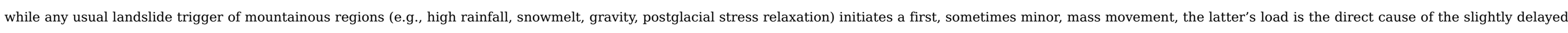
(by minutes to months) secondary larger reactivation or new landslide event.

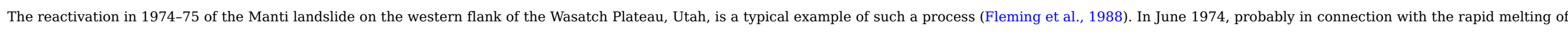

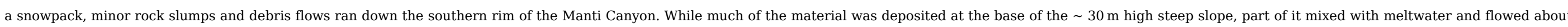

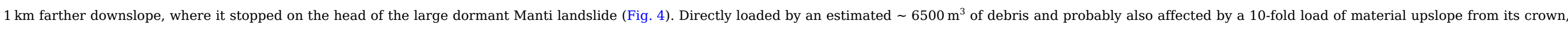

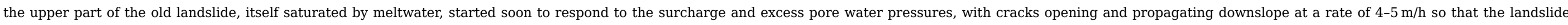

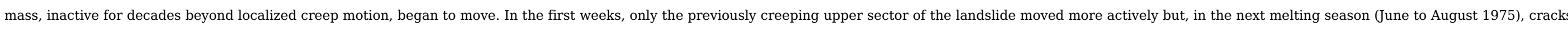

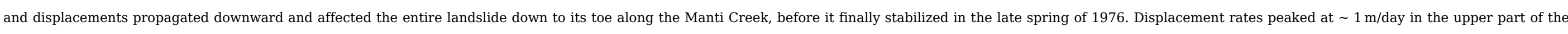
landslide, locally with a total displacement of more than $40 \mathrm{~m}$, and at $3.1 \mathrm{~m} /$ day in the landslide toe area. 


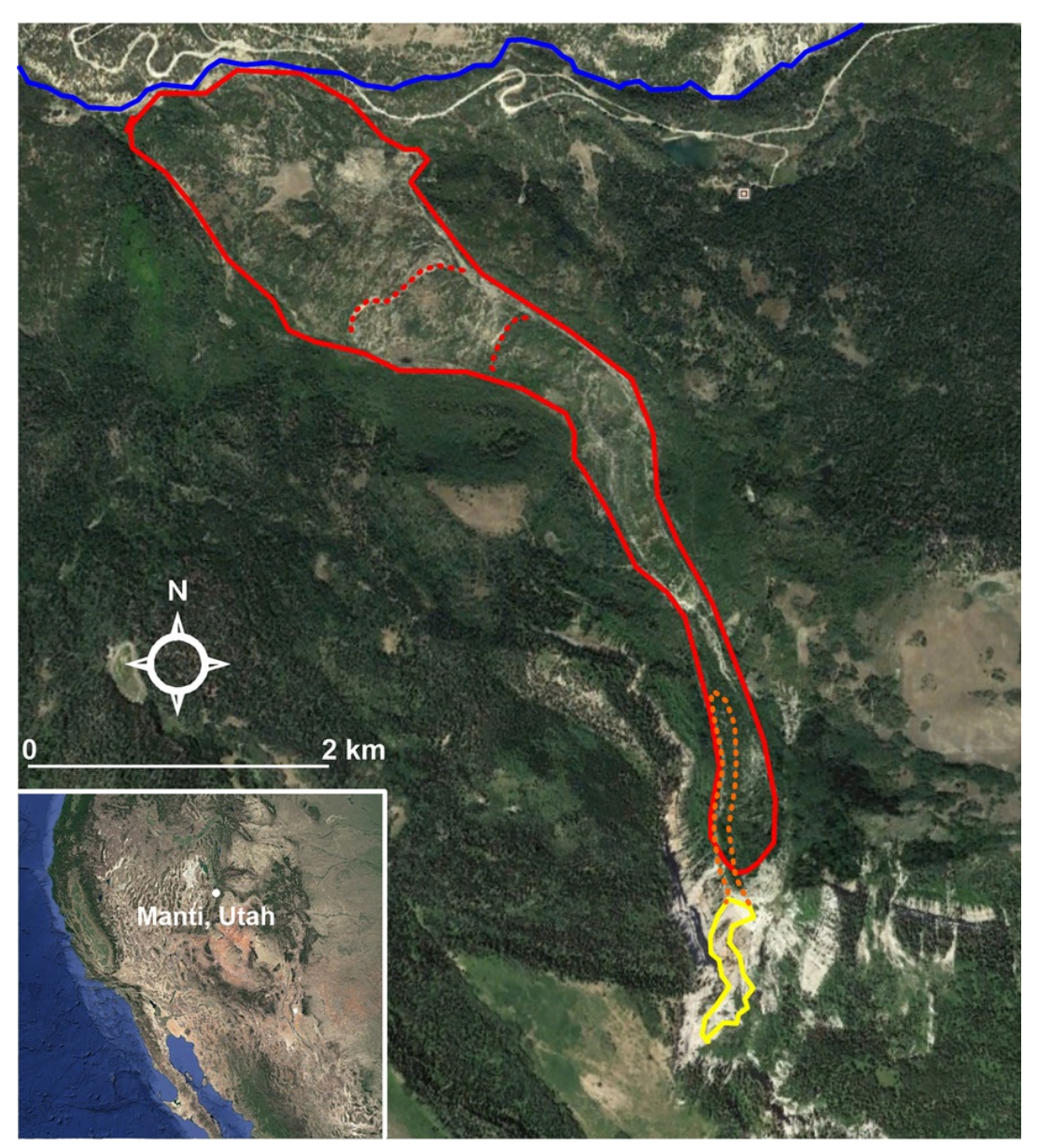

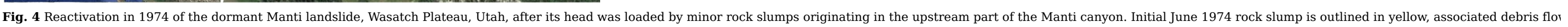
in dashed orange, dormant and reactivated Manti landslide in red.

Image 18.08.2015: @ Google Earth

alt-text: Fig. 4

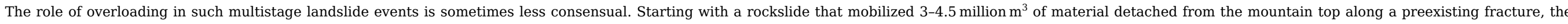

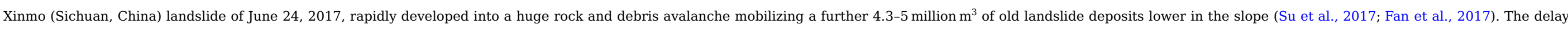

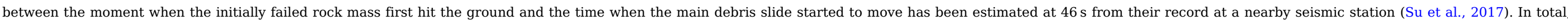

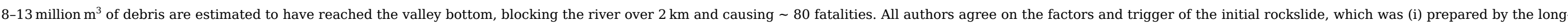

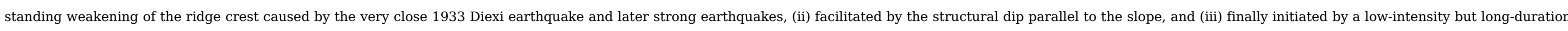

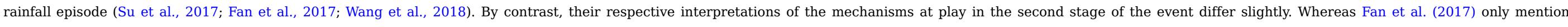

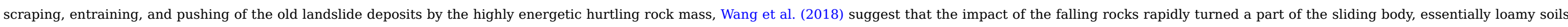

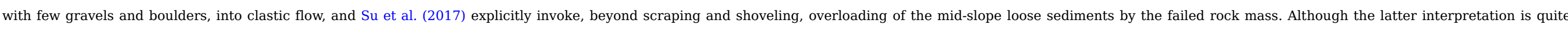

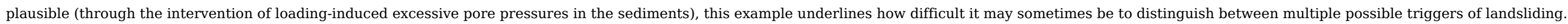




\subsection{Overloading by high soil water content}

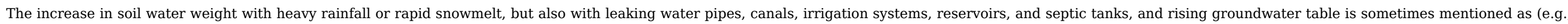

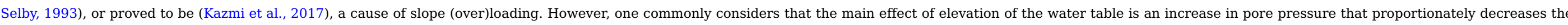

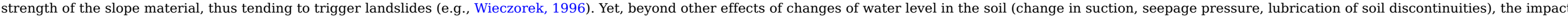

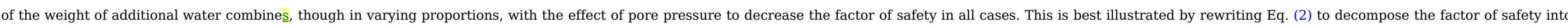
its three components according to Iverson (1991):

$$
F=F_{f}+F_{w}+F_{c}=\frac{\tan \varphi^{\prime}}{\tan \beta}-\frac{\gamma_{w} z_{w} \cos ^{2} \beta \tan \varphi^{\prime}}{\left(\gamma_{m} z_{m}+\gamma_{s a t} z_{w}\right) \cos \beta \sin \beta}+\frac{c^{\prime}+c_{r}}{\left(\gamma_{m} z_{m}+\gamma_{s a t} z_{w}\right) \cos \beta \sin \beta}
$$

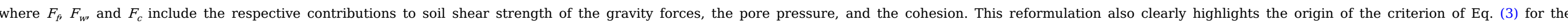

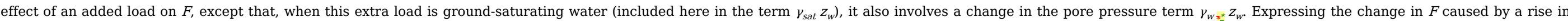
water table, rewriting

$\gamma_{\text {sat }} z_{w}=\left(\gamma_{m}+\gamma_{w} p\right) z_{w}$

with $p$ equivalent to the saturated porosity of the ground, and rearranging the relation, one obtains the following criterion for a decrease in $F$

$p\left(c^{\prime}+c_{r}\right)\left(z_{w 1}-z_{w 2}\right)<\gamma_{m} Z\left(z_{w 2}-z_{w 1}\right) \cos ^{2} \beta \tan \varphi^{\prime}$

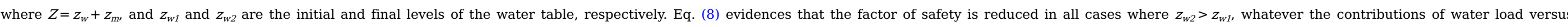
pore pressure in this decrease.

\subsection{Overloading by dense tree cover}

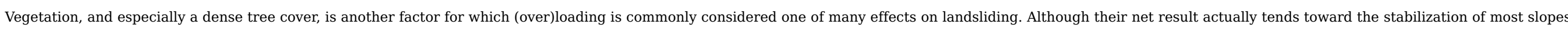
(Greenway, 1987), many of the interacting hydrological and mechanical processes governing the vegetation-soil interactions may be either beneficial or adverse to slope stability:

(1) interception by the foliage is beneficial in that enhanced evapotranspiration and water absorption reduce infiltration but excessive depletion of soil moisture may finally lead to soil cracking and higher infiltration capacity;

(2) likewise, roots extract water from the soil but in the same time the stem-root system increases soil permeability and infiltration capacity;

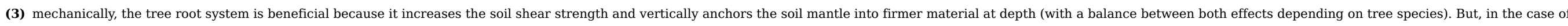

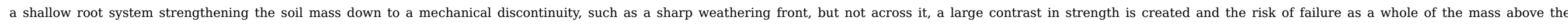
discontinuity is increased

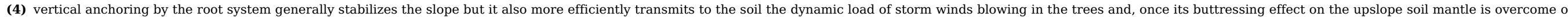
a tree is uprooted by a storm, it results in the creation of entries for concentrated water infiltration into the soil and increased slide probability

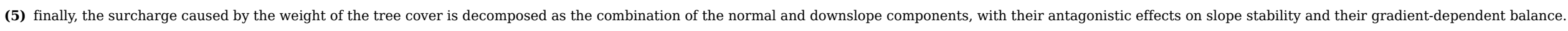

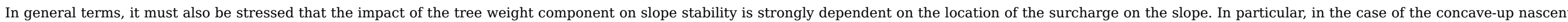

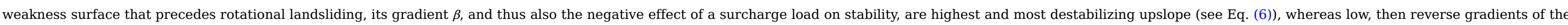
rupture surface close to the slope toe result in a tree surcharge there improving the safety factor (e.g., Genet et al., 2010).

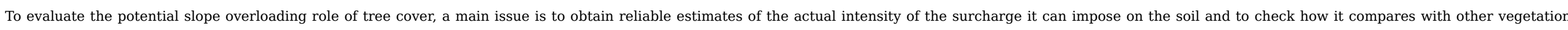

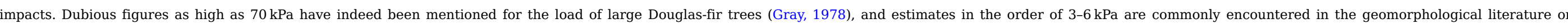

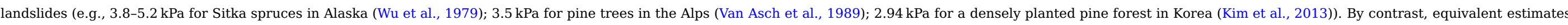
are systematically lower in the forestry literature. 


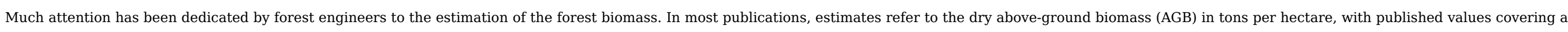

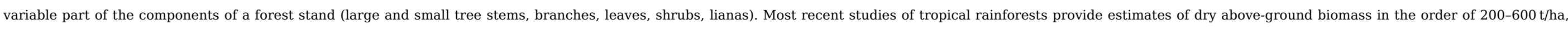

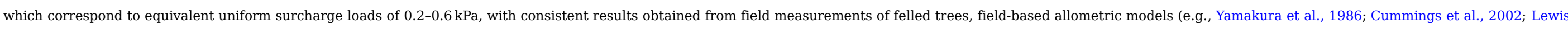

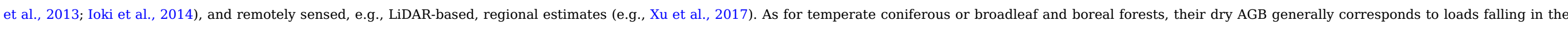

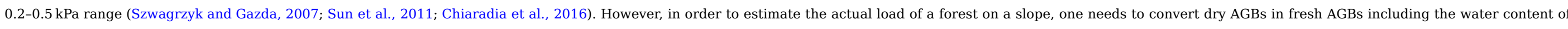

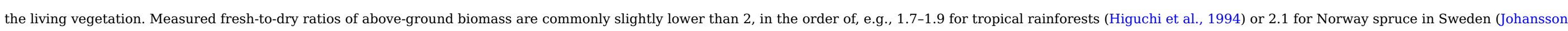

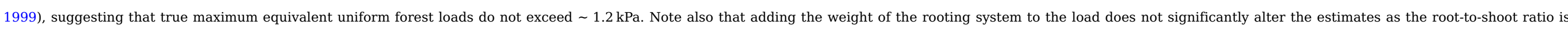
$<0.2$, for example 0.17 for Pinus spp. in S. Brazil (Sanquetta et al., 2011).

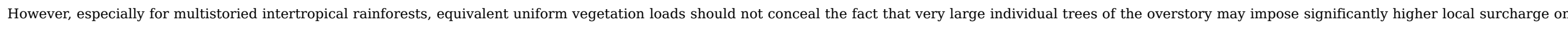

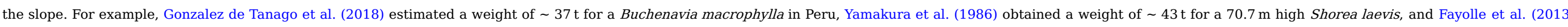

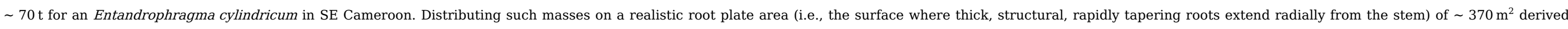
from the measured $\sim 2$-m stem diameter of these tall trees at breast height (Coder, 2014), and considering a fresh-to-dry AGB ratio of 1.8, one gets local surcharges of 1.8, 2.1, and 3.3 kPa, respectively.

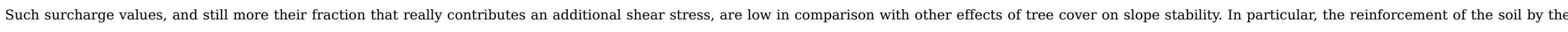

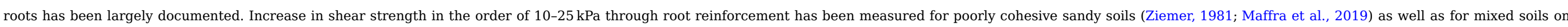

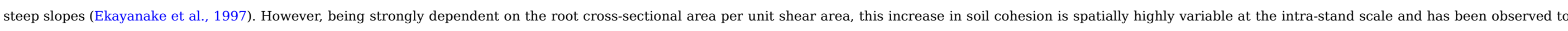

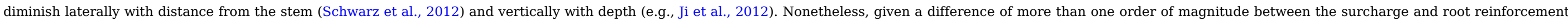

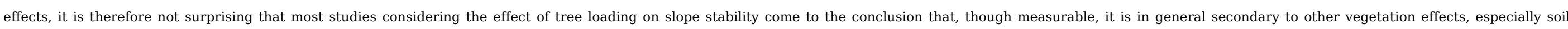
strengthening by the root system (Gray and Megahan, 1981; Abernethy and Rutherfurd, 2000) but also pore pressure alteration (Simon and Collison, 2002).

\subsection{Overloading and quick-clay landslides}

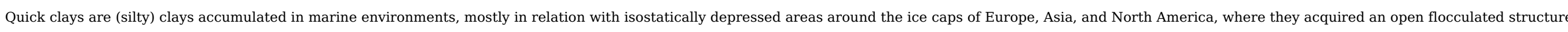

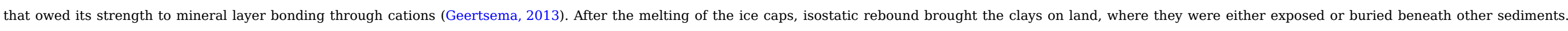

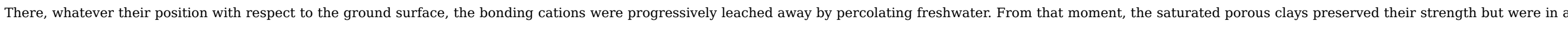

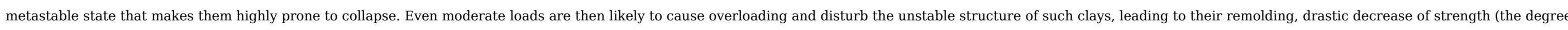

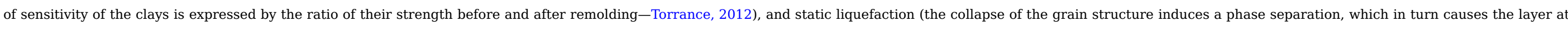
the base of the landslide to flow). This is the beginning of landsliding, which may occur on very gentle slopes and generally extends retrogressively, developing into very large landslides.

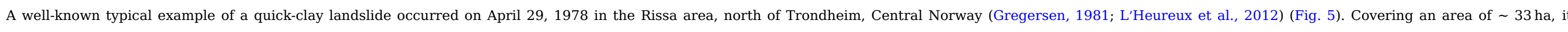

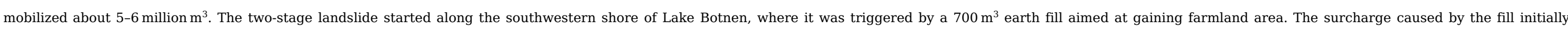

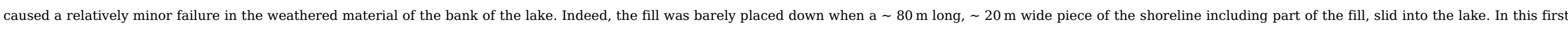

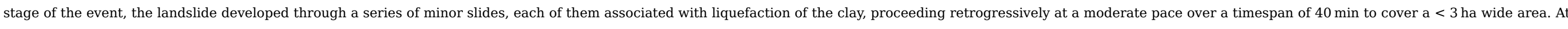

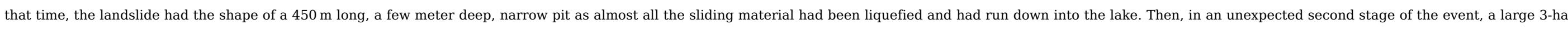

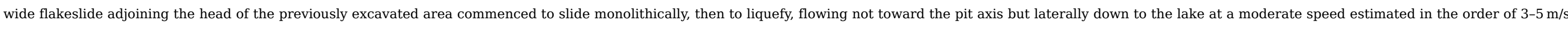

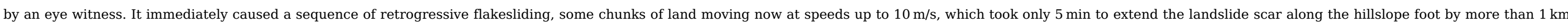
before the motion came to rest. Moreover, further damage was caused in Leiraveien, at the other end of the lake, which was reached by a $3 \mathrm{~m}$ high seiche wave (Martin et al., 2017). 


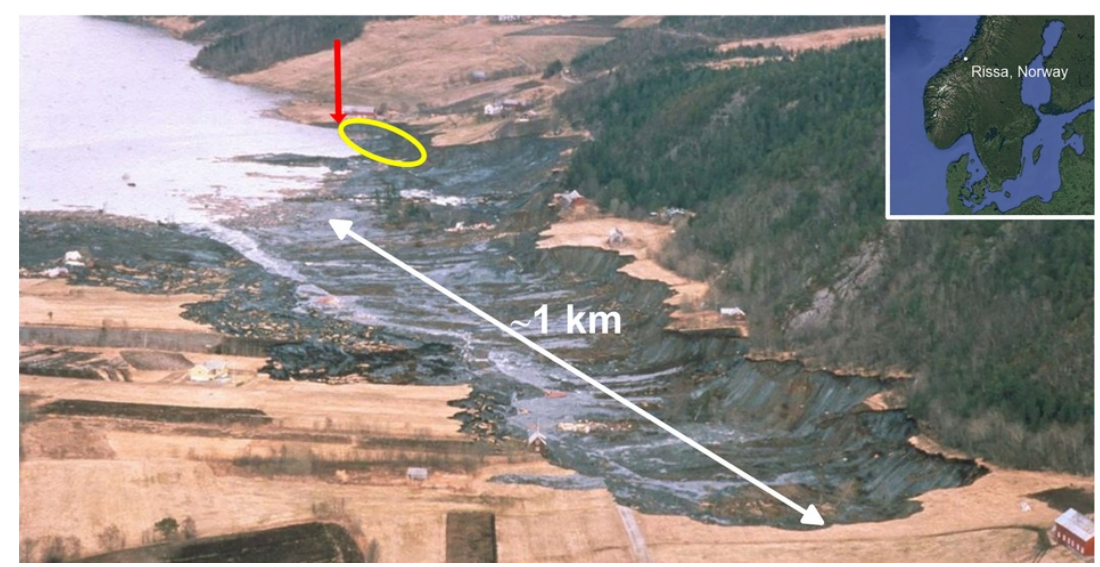

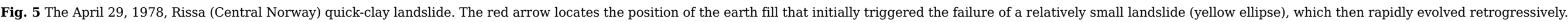
Photograph courtesy of Aftenposten.

\section{alt-text: Fig. 5}

\subsection{Seismic loading}

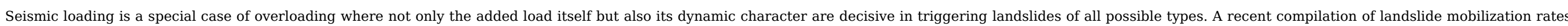

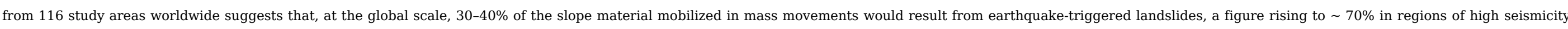

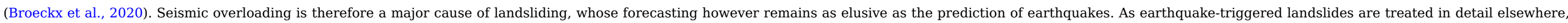
we deal here only briefly with the specific issue of how dynamic loading by propagating seismic waves acts as a surcharge responsible for slope failure.

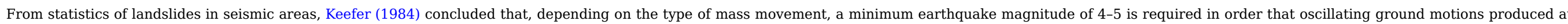

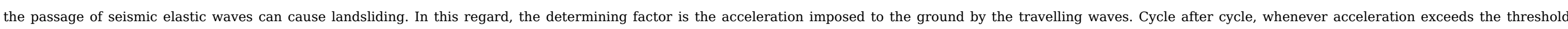

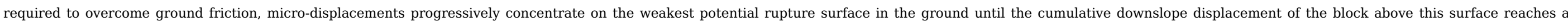

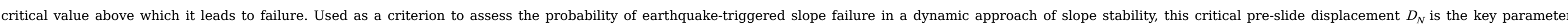

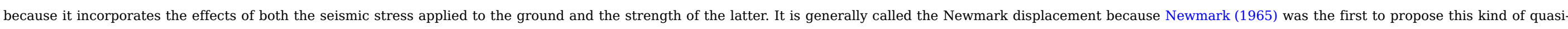

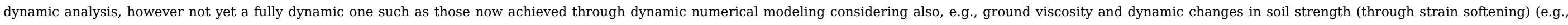

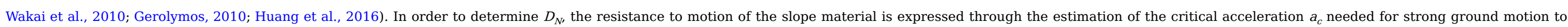
initiate sliding as

$a_{c}=(F-1) \mathrm{g} \sin \alpha$

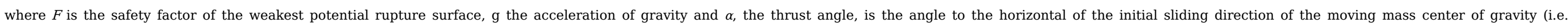

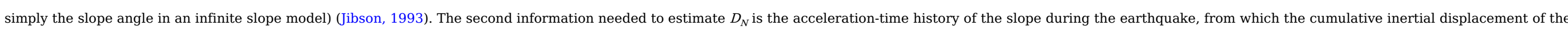

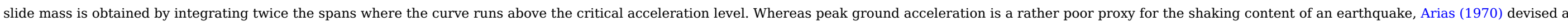
practical measure of total seismic shaking intensity, called Arias intensity $I_{A}$. Widely used in $D_{N}$ estimations, it is based on the integral of the time-domain ground acceleration and reads as

$I_{A}=\frac{\pi}{2 g} \int_{0}^{d}[a(t)]^{2} d t$

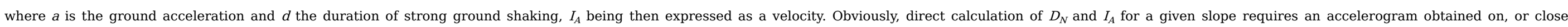
to, site but such data are not available in most cases, thus preventing direct determination of $D_{N}$. This urged Jibson (1993) to propose a simplified Newmark's method based on empirical relations. 


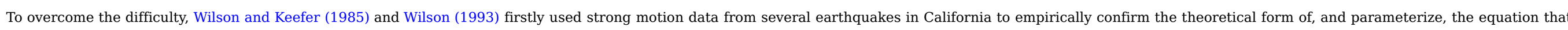

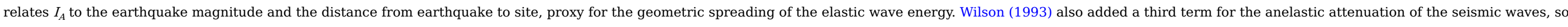
that the relation obtained for $I_{A}-$ representative of the surcharge applied to the slope by its dynamic loading-is expressed as (simplified after Wilson, 1993)

$\log I_{A}=M_{w}-2 \log R-k R-3.99+\varepsilon$

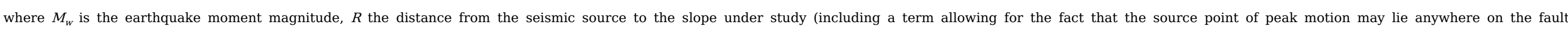

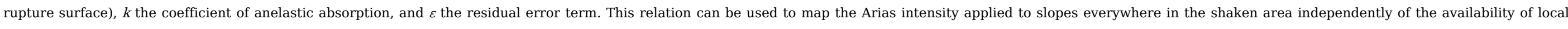

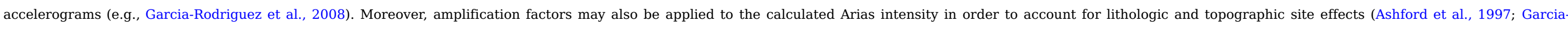
Rodriguez et al., 2008; Torgoev et al., 2013).

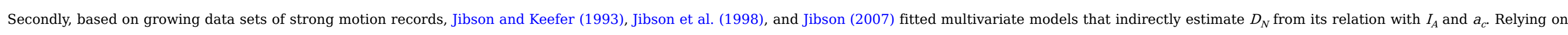

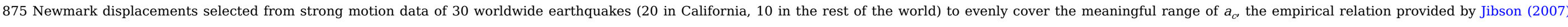
reads as

$\log D_{N}=2.401 \log I_{A}-3.481 \log a_{c}-3.230 \pm 0.656$

with $D_{N}$ in cm, $I_{A}$ in $\mathrm{m} / \mathrm{s}, a_{C}$ in $g^{\prime} \mathrm{s}$, and a coefficient of determination $R^{2}=0.71$.

More recently, using a worldwide data set of strong motion records, Hsieh and Lee (2011) showed the slightly modified equation $\log D_{N}=C_{1} \log I_{A}+C_{2} a_{c}+C_{3} a_{c} \log I_{A}+C_{4}+\varepsilon$ with $C_{1}$ to $C_{4}=$ regression coefficients, performs better in their case (1343 records from 6 earthquakes, $R^{2}=0.89$ ).

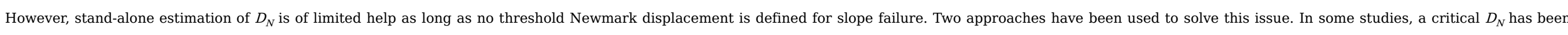

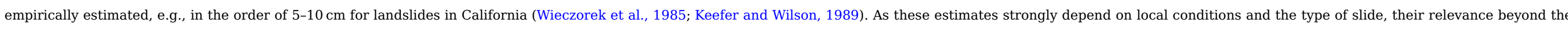

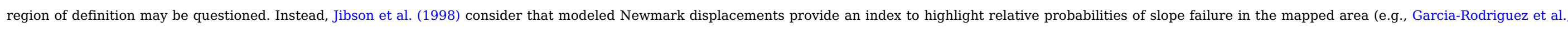
2008; Garcia-Mayordomo et al., 2009; Ma and Xu, 2019).

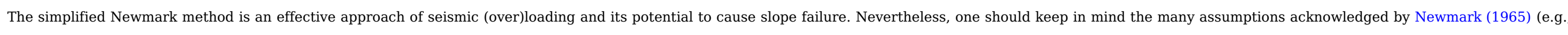

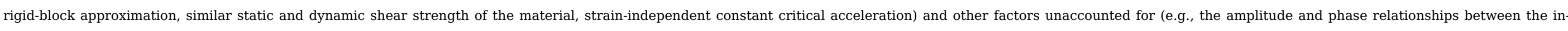
plane slope-parallel and slope-normal components of the seismic acceleration of the ground-Ingles et al., 2006; Brain et al., 2015).

\subsection{Dynamic loading of cliffs by storm waves}

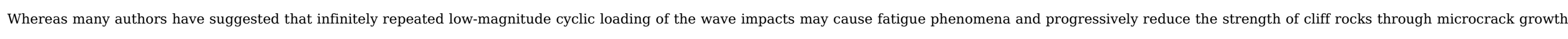

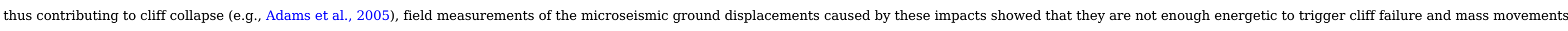

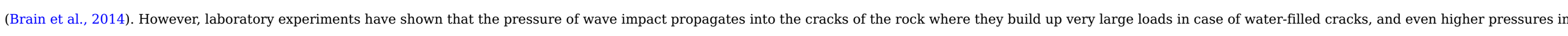

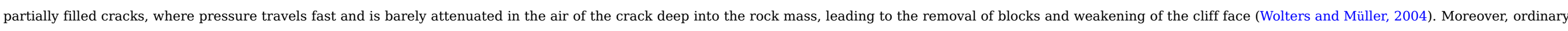

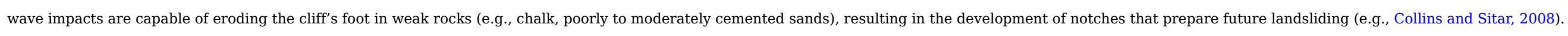

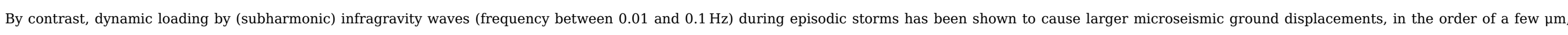

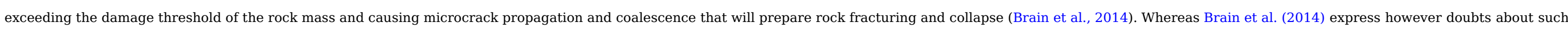

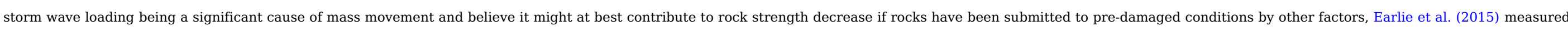

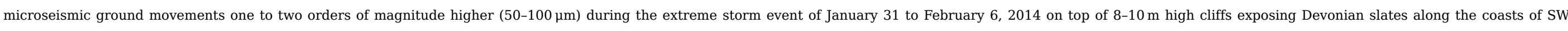

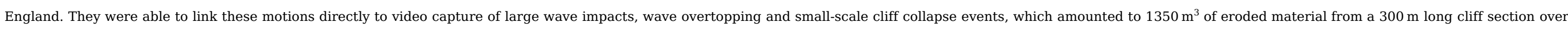

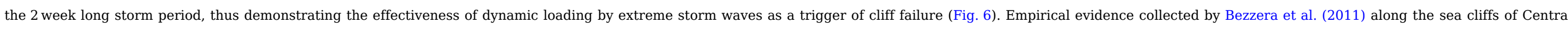




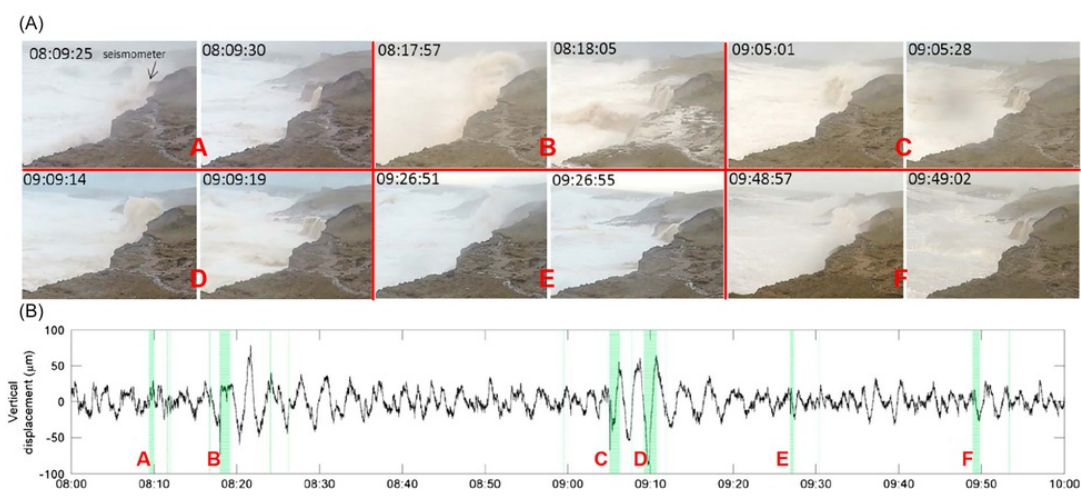

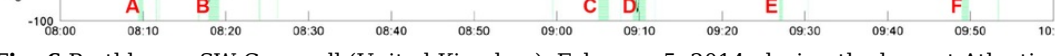

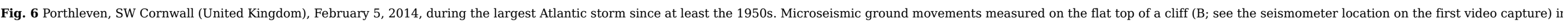
relation with successive wave overtopping and subsequent drainage events (A; pairs of successive images). Green bands in the ground motion time series correspond to the phases of water cascading down the cliff face.

From Earlie C, Young A, Masselink G and Russell P (2015) Coastal cliff ground motions and response to extreme storm waves. Geophysical Research Letters 42: 847-854, doi:10.1002/2014GL062534.

\section{alt-text: Fig. 6}

\section{7 (Local) overloading by fills and heavy constructions}

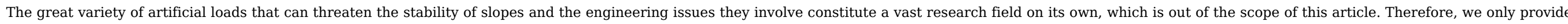
key information on the types and characteristics of such added loads and the settings in which they may impact slope stability, as it will be illustrated by a few examples.

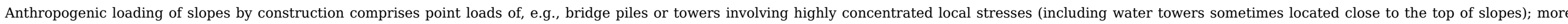

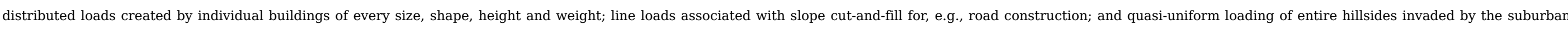

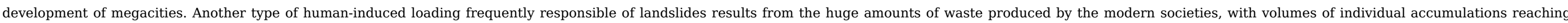

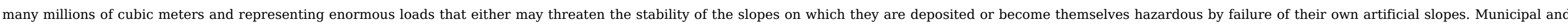

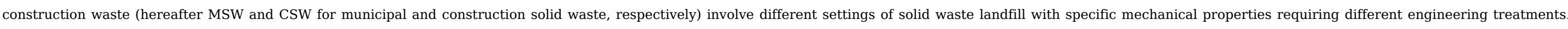

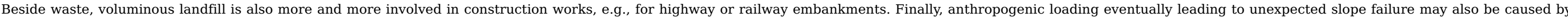

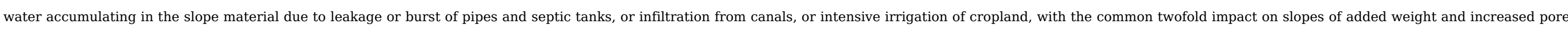
pressure (e.g., Kazmi et al., 2017).

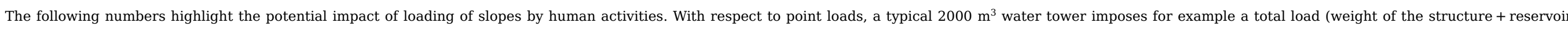

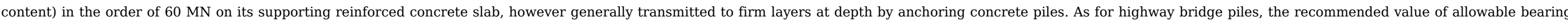

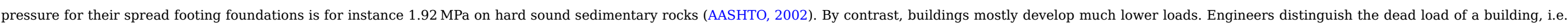

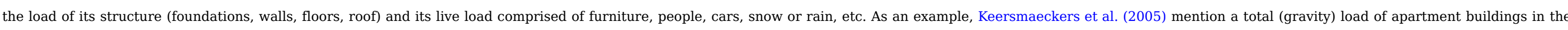

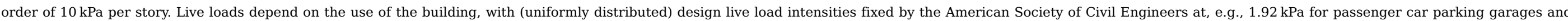

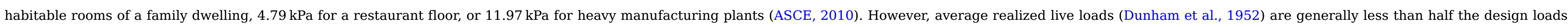

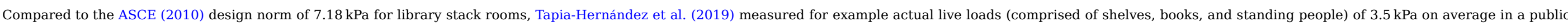

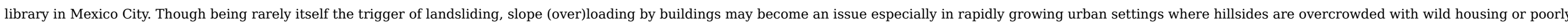

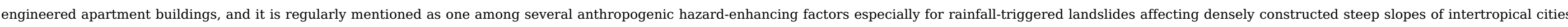




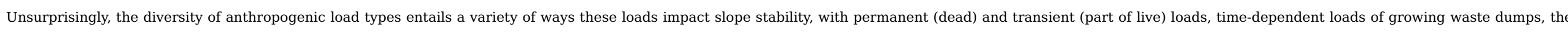

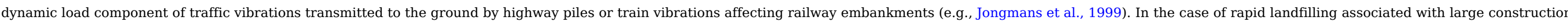

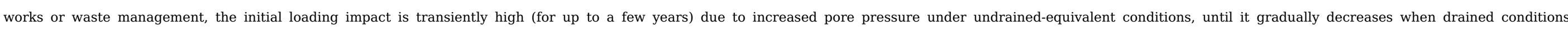

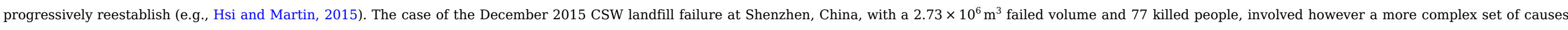

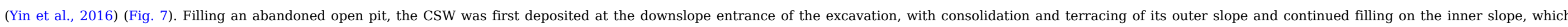

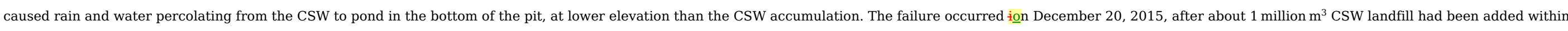

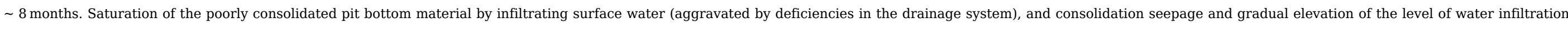
due to the continuously growing CSW accumulation combined to increase the pore pressure head in the front slope, eventually leading to excess pore pressure and slope failure.
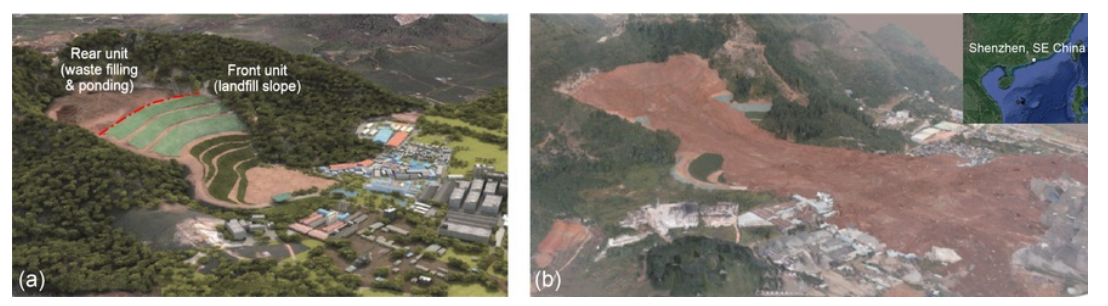

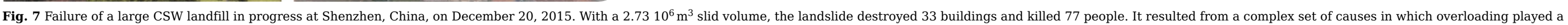

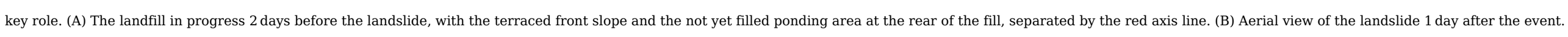

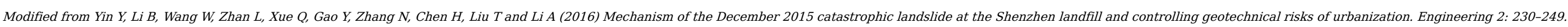
alt-text: Fig. 7

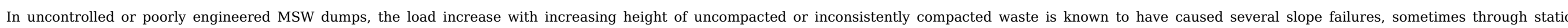

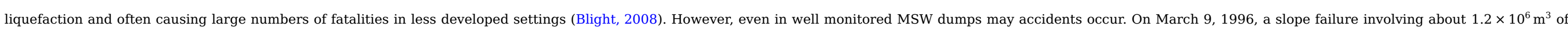

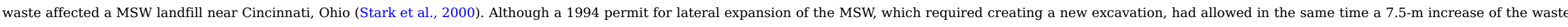

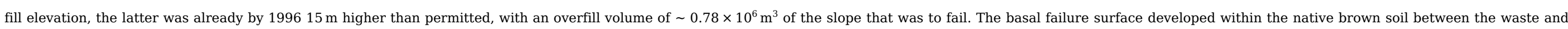

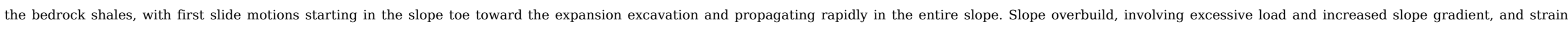

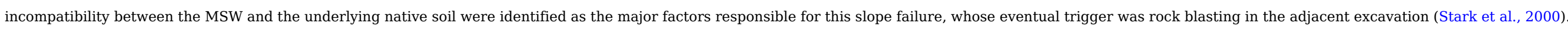

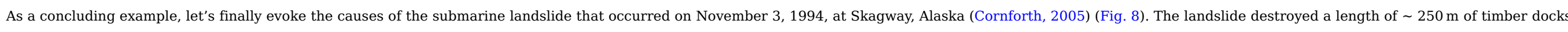

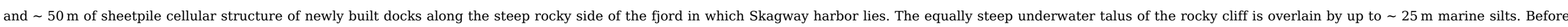

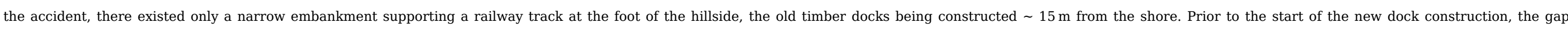

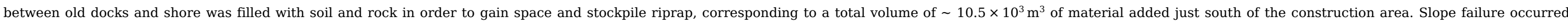

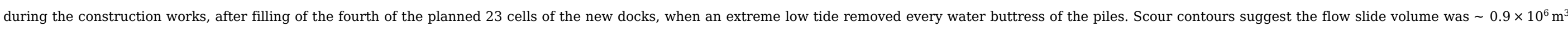

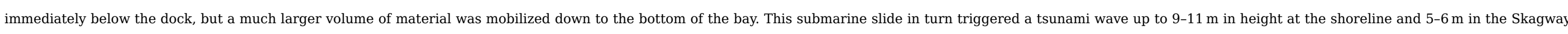

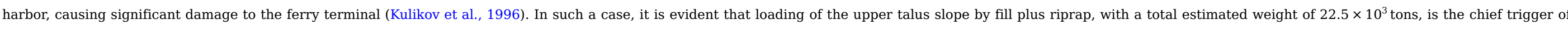

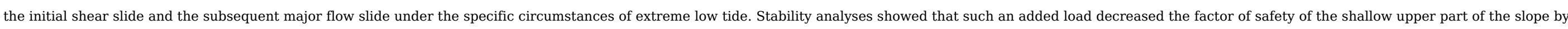

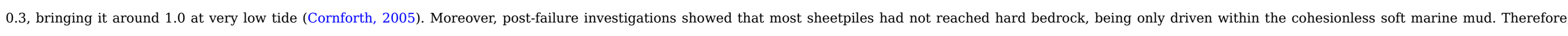
Whathowever inescapable the triggering effect of overloading may have been, the true cause of this landslide must be searched in a human lack of foresight. 


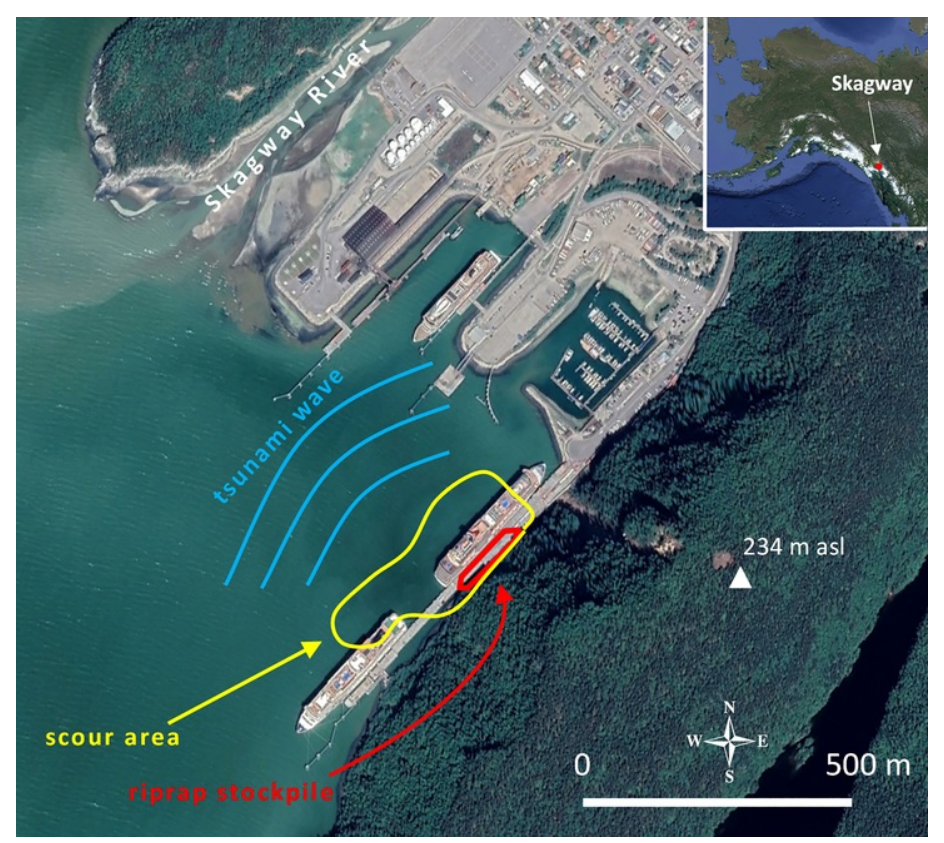

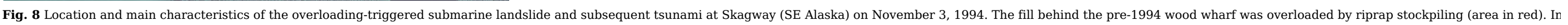
yellow, the scour area of the slide (Cornforth, 2005).

Image 14.12.2015: ๑ Google Earth.

alt-text: Fig. 8

\section{References}

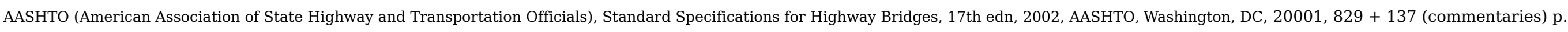
Abernethy B. and Rutherfurd I., Does the weight of riparian trees destabilize riverbanks?, Regulated Rivers Research \& Management 16, 2000, 565-576.

Adams P., Storlazzi P. and Anderson R., Nearshore wave-induced cyclical flexing of sea cliffs, Journal of Geophysical Research 110, 2005, F02002, https://doi.org/10.1029/2004JF000217.

Ancey C., Snow avalanches, In: Balmforth N. and Provenzale A., (Eds.), Geomorphological Fluid Mechanics, Lecture Notes in Physics vol. 582, 2001, Springer, 319-338.

Arias A., A measure of earthquake intensity, In: Hansen R., (Ed), Seismic Design for Nuclear Power Plants, 1970, MIT Press, Cambridge, MA, 438-483.

ASCE (American Society of Civil Engineers), Minimum design loads for buildings and other structures, In: ASCE Standards ASCE/SEI 7-10, 2010, ASCE, Reston, VA, 605p.

Ashford S., Sitar N., Lysmer J. and Deng N., Topographic effects on the seismic response of steep slopes, Bulletin of the Seismological Society of America 87 (3), $1997,701-709$.

Ashland F., Characteristics, Causes, and Implications of the 1998 Wasatch Front landslides, 2003, Utah Geological Survey, Utah, 49,-Special Study 105,49 p.

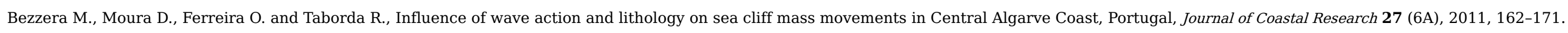

Blight G., Slope failures in municipal solid waste dumps and landfills: A review, Waste Management \& Research 26, 2008, 448-463.

Brain M., Rosser N., Norman E. and Petley D., Are microseismic ground displacements a significant geomorphic agent?, Geomorphology 207, 2014, 161-173. 


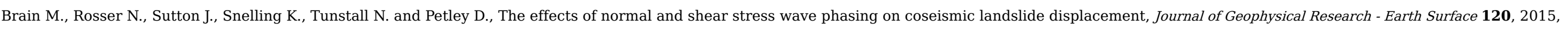
1009-1022.

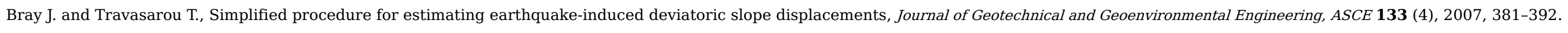

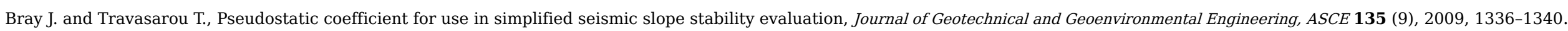

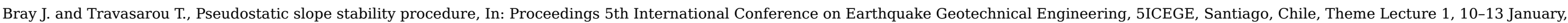
$2011 \_2011,12 \_$p.

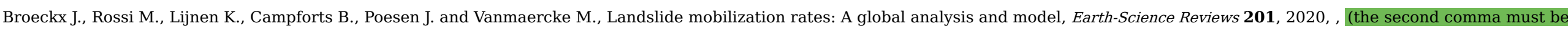
deleted.)102972_https://doi.org/10.1016/j.earscirev.2019.102972.

Calcaterra D. and Parise M., Weathering as a Predisposing Factor to Slope Movements, Engineering Geology Special Publications 2010, Bath Geological Society, 245.

Chen Z., Mi H., Zhang F. and Wang X., A simplified method for 3D slope stability analysis, Canadian Geotechnical Journal 40, 2003, 675-683.

Cheng Y., Lansivaara T. and Wei W., Two-dimensional slope stability analysis by limit equilibrium and strength reduction methods, Computers and Geotechnics 34, 2007 , 137-150.

Cheng Y., Li N. and Yang X., Three-dimensional slope stability problem with a surcharge load, Natural Hazards and Earth System Sciences 15, $2015,2227-2240$.

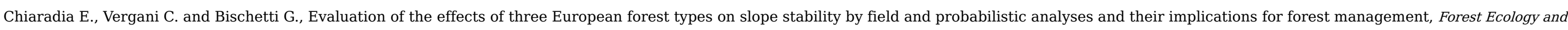
Management 370, 2016, 114-129.

Coder K., Tree Anchorage and Root Strength, 2014, University of Georgia; Warnell School of Forestry and Natural Resources Monograph Publication WSFNR14-9, 67_p.

Collins B. and Sitar N., Processes of coastal bluff erosion in weakly lithified sands, Pacifica, California, USA, Geomorphology 97, 2008, 483-501.

Cornforth D., Landslides in Practice, 2005, Wiley, 596p.

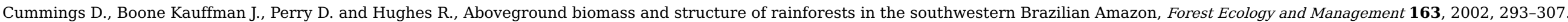
Demoulin A. and Glade T., Recent landslide activity in Manaihan, East Belgium, Landslides 1, 2004, 305-310, https://doi.org/10.1007/s10346-004-0035-z.

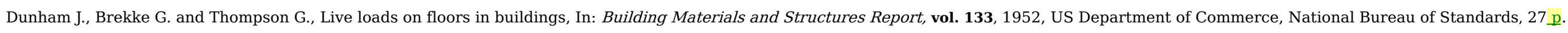
Durgin P., Landslides and the Weathering of Granitic Rocks, Reviews in Engineering Geology vol. III, 1977, Geological Society of America, 127-131.

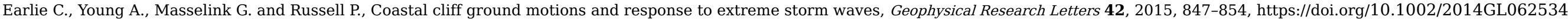

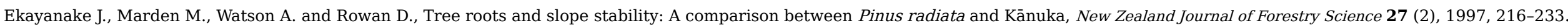

El-Ramly H., Morgenstern R. and Cruden D., Probabilistic slope stability analysis for practice, Canadian Geotechnical Journal 39, $2002,665-683$.

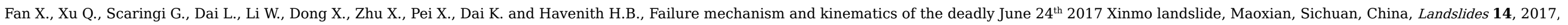
2129-2146, https://doi.org/10.1007/s10346-017-0907-7.

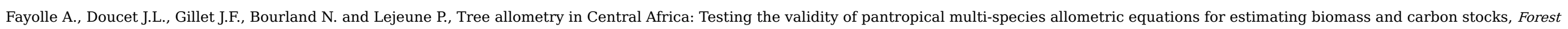
Ecology and Management 305, 2013, 29-37.

Fellenius W., Erdstatische Berechnungen mit Reibung und Kohäsion (Adhäsion) und unter Annahme kreiszylindrischer Gleitflächen, 1927, W. Ernst \& Sohn, Berlin, 40_p. 
Fleming R., Johnson R. and Schuster R., The reactivation of the Manti landslide, Utah, In: USGS Professional Paper 1311, The Manti, Utah, Landslide $\_1988,1_{1-22 .}$

Froude M. and Petley D., Global fatal landslide occurrence from 2004 to 2016, Natural Hazards and Earth System Sciences 18, 2018, 2161-2181, https://doi.org/10.5194/nhess-18-2161-2018.

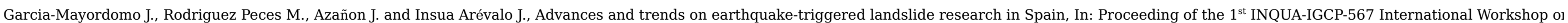

Earthquake Archaeology and Palaeoseismology, Baelo Claudia, Spain, 7-13 September 2009_2009, 28-31.

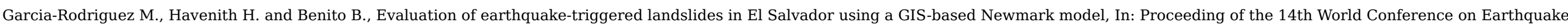

Engineering, October 12-17, 2008, Beijing, China $\_2008$.

Geertsema M., Quick clay, In: Bobrowsky P., (Ed), Encyclopedia of Natural Hazards, 2013, Springer, 803-804.

Genet M., Stokes A., Fourcaud T. and Norris J., The influence of plant diversity on slope stability in a moist evergreen deciduous forest, Ecological Engineering 36 (3), 2010, 265-275.

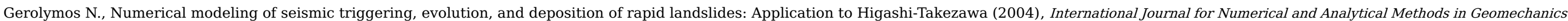

34, 2010, 383-407.

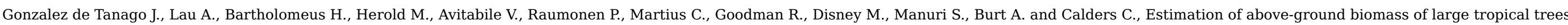
with terrestrial LiDAR, Methods in Ecology and Evolution 9, 2018, 223-234.

Gray D., Role of woody vegetation in reinforcing soils and stabilising slopes, In: Proceeding of the Symposium Soil Reinforcing and Stabilising Techniques, Sydney, Australia $\_1978,253-306$.

Gray D. and Megahan W., Forest Vegetation Removal and Slope Stability in the Idaho Batholith, USDA, Research Paper INT-271: Ogden, Utah. 1981, 23_p.

Greenway D., Vegetation and slope stability, In: Anderson M. and Richards K., (Eds.), Slope Stability, Geotechnical Engineering and Geomorphology 1987, Wiley, 187-230.

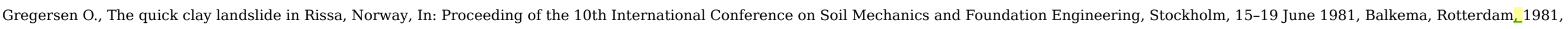

$421-426$.

Griffiths D. and Lane P., Slope stability analysis by finite elements, Geotechnique 49 (3), 1999, 387-403.

Hammond C., Hall D., Miller S. and Swetik P., Level I Stability Analyses (LISA) Documentation for Version 2.0, USDA, General Technical Reports INT-285: Ogden, Utah. 1992, 190_p.

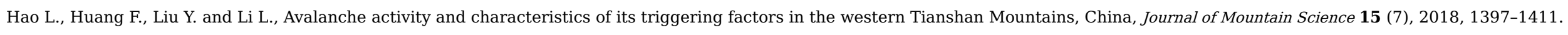

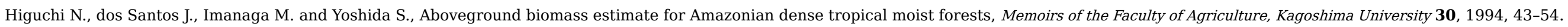

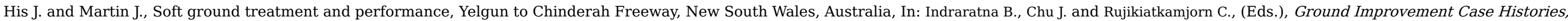

Compaction, Grouting and Geosynthetics ${ }_{\iota}$ 2015, Elsevier, 137-174.

Hsieh S. and Lee C., Empirical estimation of the Newmark displacement from the Arias intensity and critical acceleration, Engineering Geology 122, $2011,34-42$.

Huang C. and Tsai C., New method for 3D and asymmetrical slope stability analysis, Journal of Geotechnical and Geoenviromental Engineering 126 (10), 2000 , 917-927.

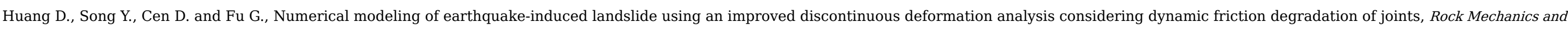
Rock Engineering 49, 2016, 4767-4786.

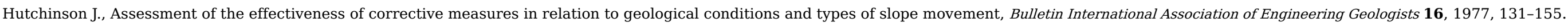

Hutchinson J., An influence line approach to the stabilization of slopes by cuts and fills, Canadian Geotechnical Journal 21, 1984, 363-370.

Hynes-Griffin M. and Franklin A., Rationalizing the Seismic Coefficient Method, Miscellaneous Paper GL-84-13. 1984, US Army Engineer WES, Vicksburg, MS, 21_p., + annexes. 


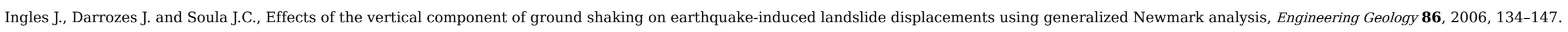

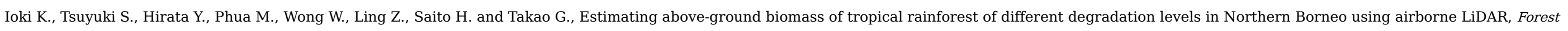
Ecology and Management 328, 2014, 335-341.

Iverson R., Sensitivity of stability analyses to groundwater data, In: Bell D., (Ed), Proceedings of the Sixth International Symposium on Landslides, Balkema $1991,451-457$.

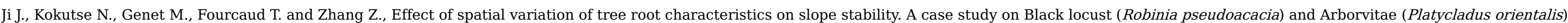
stands on the loess Plateau, China, Catena 92, 2012, 139-154.

Jibson R., Predicting earthquake-induced landslide displacements using Newmark's sliding block analysis, Transportation Research Record 1411, $1993,9-17$.

Jibson R., Regression models for estimating coseismic landslide displacement, Engineering Geology 91, 2007, 209-218.

Jibson R. and Keefer D., Analysis of the seismic origin of landslides: Examples from the New Madrid seismic zone, Geological Society of America Bulletin 105, 1993, 521-536.

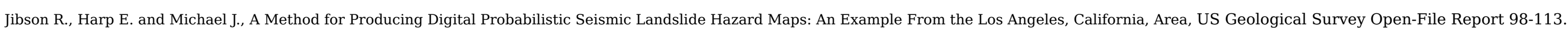
1998, 17_p.

Johansson T., Biomass production of Norway spruce (Picea abies (L.) Karst.) growing on abandoned farmland, Silva Fennica 33 (4), $1999,261-280$.

Jones F., Landslides of Rio de Janeiro and the Serra das Araras Escarpment, Brazil, U.S. Geological Survey Professional Paper 697. 1973, 42_p.

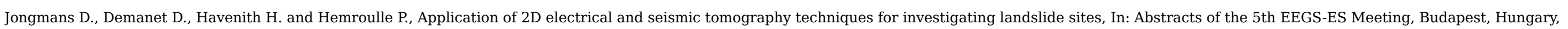
September 6-9, 1999, EAGE Publications, LS-03_1999, 2p.

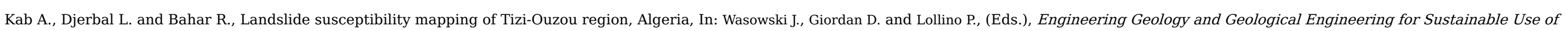
the Earth's Resources, Urbanization and Infrastructure Protection From Geohazards, 2018, Springer International Publishing AG, $140-148$.

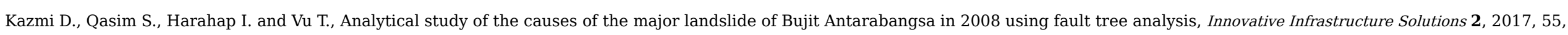
https://doi.org/10.1007/s41062-017-0105-4.

Keefer D., Landslides caused by earthquakes, Geological Society of America Bulletin 95, 1984, 406-421.

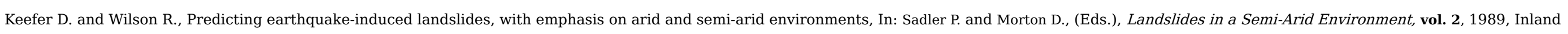
Geological Society, Riverside, CA, 118-149.

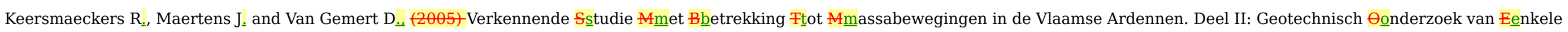

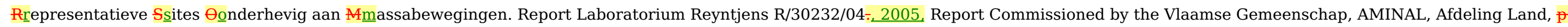
$154 \_$p.

Kim D., Im S., Lee C. and Woo C., Modeling the contribution of trees to shallow landslide development in a steep, forested watershed, Ecological Engineering $\mathbf{6 1 P}, 2013,658-668$.

Krahn J., The 2001 R.M. Hardy lecture: The limits of limit equilibrium analyses, Canadian Geotechnical Journal 40, 2003, 643-660.

Kulikov E., Rabinovich A., Thomson R. and Bornhold B., The landslide tsunami of November 3, 1994, Skagway Harbor, Alaska, Journal of Geophysical Research 101 (C3), $1996,6609-6615$.

Laws M. and Murray J., Impacts of poor urban land development on slope instability, In: Geohazard Conference 2011, Kelowna, British Columbia, Canada_2011, 8_p.

Lewis S., et al., Above-ground biomass and structure of 260 African tropical forests, Philosophical Transactions of the Royal Society B 368, 2013, , (delete the second

comma)20120295_https://doi.org/10.1098/rstb.2012.0295. 


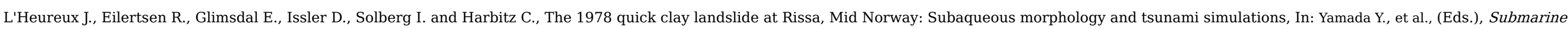
Mass Movements and Their Consequences, Advances in Natural and Technological Hazards Research vol. 31, 2012, Springer, 507-516.

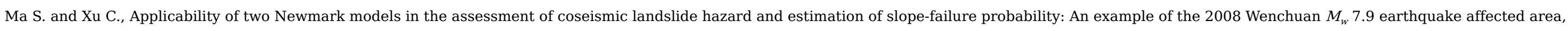
Journal of Earth Science 30 (5), 2019, 1020-1030.

Maffra C., Sousa R., Sutili F. and Pinheiro R., The effect of roots on the shear strength of texturally distinct soils, Floresta e Ambiente 26 (3), 2019 , , 8087.101817.

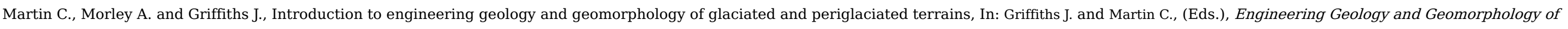

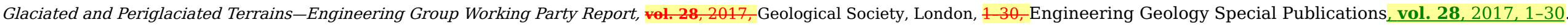

Matsui T. and San K., Finite element slope stability analysis by shear strength reduction technique, Soils and Foundations 32 (1), 1992, 59-70.

Mulder H., Assessment of Landslide Hazard, PhD thesis. 1991, Utrecht University, Utrecht, 149p.

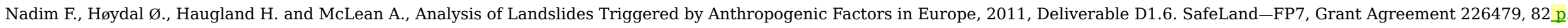

Naylor D., Finite elements and slope stability, Numerical methods, In: Geomechanics, Proceedings of the NATO Advanced Study Institute, Lisbon $\_1981,229-244$.

Newmark N., Effects of earthquakes on dams and embankments, Geotechnique 15 (2), 1965, 139-160.

Sanquetta C., Corte A. and da Silva F., Biomass expansion factor and root-to-shoot ratio for Pinus in Brazil, Carbon Balance and Management 6, $2011,6$.

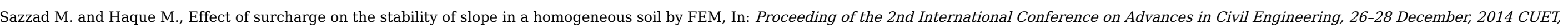
Chittagong, Bangladesh, 2014, 314-318

Schwarz M., Cohen D. and Or D., Spatial characterization of root reinforcement at stand scale: Theory and case study, Geomorphology 171-172, 2012, 190-200.

Seed H., Considerations in the earthquake-resistant design of earth and rockfill dams, Geotechnique 29 (3), 1979, 215-263.

Selby M., Hillslope Materials and Processes, 2nd edn, 1993, Oxford University Press, Oxford, 451_p.

Simon A. and Collison A., Quantifying the mechanical and hydrologic effects of riparian vegetation on streambank stability, Earth Surface Processes and Landforms 27, 2002, 527-546.

Smyth C. and Royle S., Urban landslide hazards: Incidence and causative factors in Niterói, Rio de Janeiro State, Brazil, Applied Geography 20, $2000,95-117$.

Speight J. and Isbell R., Substrate, The National Committee on Soil and Terrain (Ed.). In: Australian Soil and Land Survey Field Handbook, 2009, CSIRO, 201-224.

Stark T., Eid H., Evans W. and Sherry P., Municipal solid waste slope failure II: Stability analyses, Journal of Geotechnical and Geoenviromental Engineering 126 (5), $2000,408-419$.

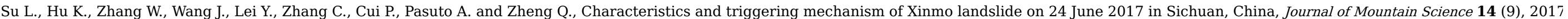
1689-1700.

Sun G., Ranson K., Guo Z., Zhang Z., Montesano P. and Kimes D., Forest biomass mapping from lidar and radar synergies, Remote Sensing of Environment 115, 2011, 2906-2916.

Szwagrzyk J. and Gazda A., Above-ground standing biomass and tree species diversity in natural stands of Central Europe, Journal of Vegetation Science 18, 2007, 555-562.

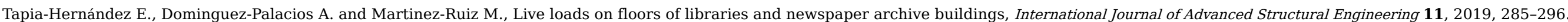

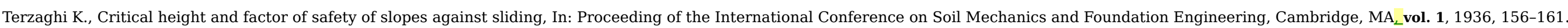




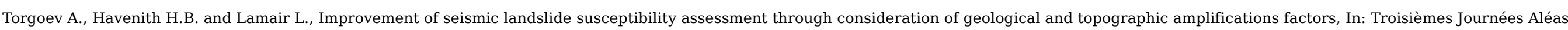
Gravitaires, Grenoble, France, 17-18 Septembre 2013_2013, 6_p.

Torrance J., Landslides in quick clay, In: Clague J. and Stead D., (Eds.), Landslides: Types, Mechanisms and Modeling, 2012, Cambridge University Press, 83-94.

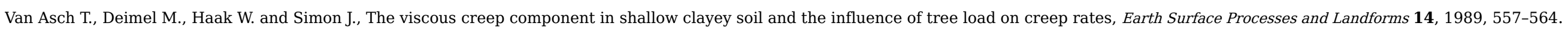

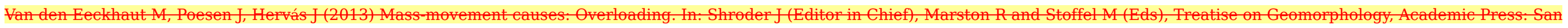
Diege, CA, vol. 7, Mountain and Hillslope Geomorphology, 1st edn, pp. 200206.

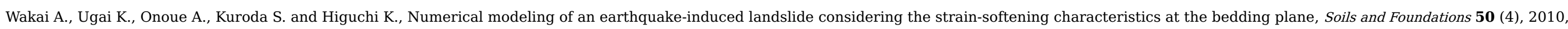
533-545.

Wan Y., Gao Y. and Zhang F., A simplified approach to determine the unique direction of sliding in 3D slopes, Engineering Geology 211, 2016, 179-183.

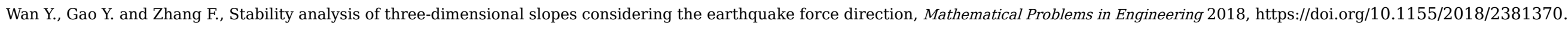

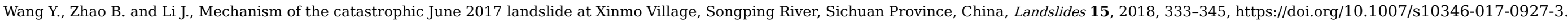
Ward T., Factor of Safety Approach to Landslide Potential Delineation, PhD Thesis. 1976, Colorado State University, Fort Collins, 128_p.

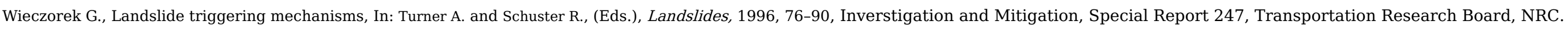

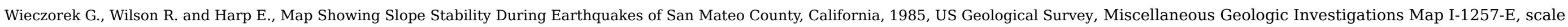
$1: 62,500$.

Wilson R., Relation of Arias Intensity to Magnitude and Distance in California, 1993, US Geological Survey, 42, Open-File Report 93-556,42 p.

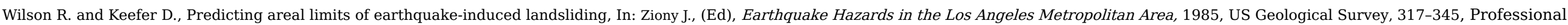
Paper 1360.

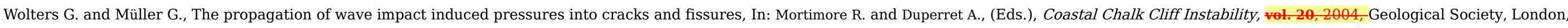
121 130, Engineering Geology Special Publications, vol. 20, 2004, 121-130.

Wu T., McKinnell W. and Swanston D., Strength of tree roots and landslides on Prince of Wales Island, Alaska, Canadian Geotechnical Journal 16, $1979,19-33$.

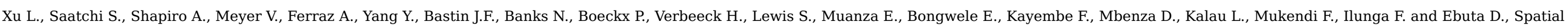
distribution of carbon stored in forests of the Democratic Republic of Congo, Scientific Reports 7, 2017, 15030, https://doi.org/10.1038/s41598-017-15050-z.

Yamakura T., Hagihara A., Sukardjo S. and Ogawa H., Aboveground biomass of tropical rain forest stands in Indonesian Borneo, Vegetatio 68, $1986,71-82$.

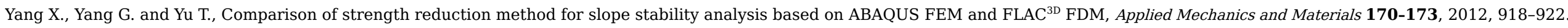

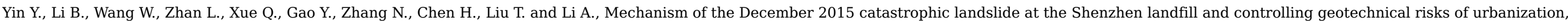
Engineering 2, 2016, 230-249.

Ziemer R., Roots and the stability of forested slopes, In: Erosion and Sediment Transport in Pacific Rim Steeplands, 132, 1981, IAHS Publishing, Christchurch, 343-361.

Zienkiewicz O., Humpheson C. and Lewis R., Associated and non-associated visco-plasticity and plasticity in soil mechanics, Geotechnique 25 (4), $1975,671-689$. 


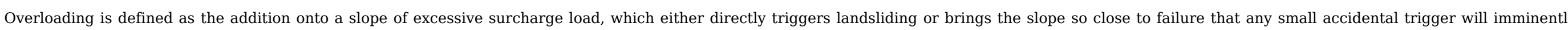

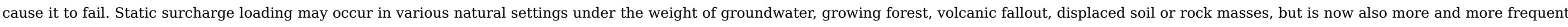

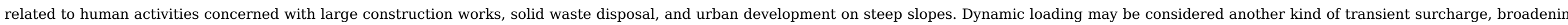

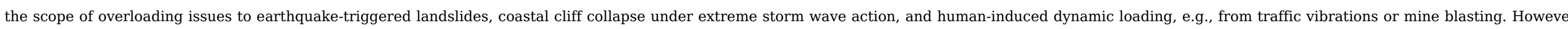

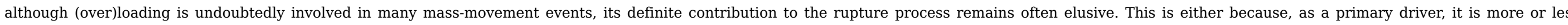

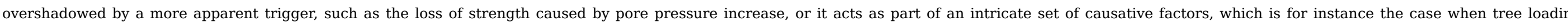

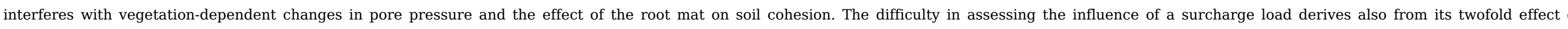

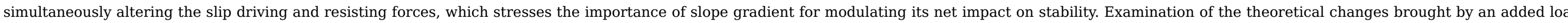
to the formulation of the factor of safety and up-to-date stability analyses help to unravel the issue.

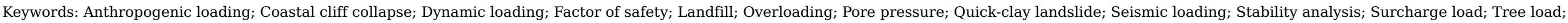

\section{Waste dump}

\section{Queries and Answers}

Query:

Please check whether the author names and affiliations are correct.

Answer: see the correction in affiliation b

Query:

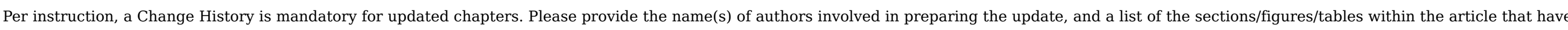
been updated.

Answer: this is not an updated chapter but a quite next text on the same entry, written by new authors. There is thus no relation between this text and that of the first edition.

\section{Query:}

Please check if reference has to be cited in place of "and many others".

Answer: no reference has to be provided in place of "and many others".

Query:

Per style, cross references to other articles are not allowed within the text. Hence they have been deleted.

\section{Answer: OK}

Query:

Please check if the value " $2.73 \times 10^{6 "}$ has been displayed correctly.

Answer: yes, it is OK so.

Query:

Please check if the value " $1.2 \times 10^{6 "}$ has been displayed correctly.

Answer: yes, it is OK so. 
Query:

Please check if the value " $\sim 0.78 \times 10^{6 ”}$ has been displayed correctly.

Answer: yes, it is OK so.

Query:

Please check if the value " $10.5 \times 10^{3 "}$ has been displayed correctly.

Answer: yes, it is OK so.

Query:

Please check if the value " $0.9 \times 10^{6 "}$ has been displayed correctly.

Answer: yes, it is OK so.

Query:

Please check if the value " $22.5 \times 10^{3 "}$ has been displayed correctly.

Answer: yes, it is OK so.

Query:

The references " "Van den Eeckhaut et al., 2013"" occur in the reference list but not in the body of the text. Please position each reference in the text or, alternatively, delete it. Thank you.

Answer: OK. We have deleted it. 